OPEN ACCESS

Edited by:

Kyung-Ja Ha,

Pusan National University,

South Korea

Reviewed by:

Renguang Wu,

Institute of Atmospheric Physics

(CAS), China

Wen Chen,

Institute of Atmospheric Physics

(CAS), China

*Correspondence:

William K. M. Lau

wkmlau@umd.edu

Specialty section:

This article was submitted to

Atmospheric Science,

a section of the journal

Frontiers in Earth Science

Received: 29 April 2020

Accepted: 27 May 2020

Published: 19 June 2020

Citation:

Lau WKM, Kim K-M, Zhao C, Leung LR and Park S-H (2020) Impact of Dust-Cloud-Radiation-Precipitation

Dynamical Feedback on

Subseasonal-to-Seasonal Variability of the Asian Summer Monsoon

in Global Variable-Resolution

Simulations With MPAS-CAM5.

Front. Earth Sci. 8:226.

doi: 10.3389/feart.2020.00226

\section{Impact of}

\section{Dust-Cloud-Radiation-Precipitation} Dynamical Feedback on Subseasonal-to-Seasonal Variability of the Asian Summer Monsoon in Global Variable-Resolution Simulations With MPAS-CAM5

\author{
William K. M. Lau'*, Kyu-Myong Kim², Chun Zhao ${ }^{3,4}$, L. Ruby Leung ${ }^{5}$ and \\ Sang-Hun Park ${ }^{6}$
}

\begin{abstract}
${ }^{1}$ Earth System Science Interdisciplinary Center, University of Maryland, College Park, MD, United States, ${ }^{2}$ NASA Laboratory for Atmospheric Sciences, Goddard Space Flight Center, Greenbelt, MD, United States, ${ }^{3}$ School of Earth and Space Sciences, University of Science and Technology of China, Hefei, China, ${ }^{4}$ CAS Center for Excellence in Comparative Planetology, University of Science and Technology of China, Hefei, China, ${ }^{5}$ Pacific Northwest National Laboratory, Richland, WA, United States, ${ }^{6}$ Department of Atmospheric Sciences, Yonsei University, Seoul, South Korea
\end{abstract}

In this study, we investigate the effects of increased dust emission from the Middle East deserts on subseasonal-to-seasonal (S2S) variability of the Asian summer monsoon (ASM). Numerical experiments are performed using the Model for Prediction Across Scales (MPAS) coupled with the Community Atmosphere Model (CAM5) physics, with regional refinement at $30 \mathrm{~km}$ grid resolution over South Asia and the surrounding regions. Result shows that increased dust emission and transport from the Middle East/West Asia region induces a strong dust-cloud-radiation-precipitation-circulation feedback, resulting in a colder surface over the desert regions and the western Tibetan Plateau, but warmer and moister troposphere with enhanced cloudiness and precipitation over the Pakistan/Northwest India (PNWI) region. The latter changes are amplified by the dust aerosol induced Elevated Heat Pump (EHP) mechanism along the West Himalayas/Iranian Plateau foothill regions, most pronounced during MayJune. During July-August, cloud radiation feedback further enhances the warming of the upper troposphere, and cooling of the land surface over the PNWI and adjacent regions over West Asia. The upper tropospheric heating and increased precipitation over PNWI spur a large-scale anomalous Rossby wavetrain and a northward displacement of the subtropical jetstream, manifesting in a contraction of the South Asian High and westward shift of the Western Pacific Subtropical High. As a result, the entire ASM precipitation-cloud system is displaced westward. Precipitation and cloudiness are intensified over northwest and western India and west Asia, but suppressed over southern and central East Asia. Analyses of the S2S variability of the upper level 
vorticity balance suggests that heating by Middle East dust plays an important role in exciting, and anchoring a teleconnection pattern through interactions among dustcloud radiation, precipitation heating over the PNWI, the development of an upper level Rossby wavetrain, and the northward shift of the boreal summer jetstream over Eurasia.

Keywords: Asian summer monsoon, Middle East dust, Tibetan Plateau, aerosol-cloud radiative feedback, elevated heat pump, Rossby wavetrain, jetstream displacement, subseasonal-to-seasonal variability

\section{INTRODUCTION}

Light absorbing aerosols (LAA) consisting mainly of dust, black carbon (BC), organic carbon (OC) are well known to have strong impact on climate change in Asian summer monsoon (ASM) regions (Ramanathan et al., 2005; Lau et al., 2006, 2008, 2010; Meehl et al., 2008; Rosenfeld et al., 2008; Satheesh et al., 2008; Wang et al., 2009a,b; Bollasina et al., 2011; Sanap and Pandithurai, 2015; Li et al., 2016; Wu et al., 2016; Chu et al., 2018). From May through August, increasing monsoon southwesterlies transport large quantities of desert dusts from the Middle East across the Arabian Sea to the Indian subcontinent (Satheesh and Srinivasan, 2002; Deepshikha et al., 2005; Satheesh et al., 2006; Gautam et al., 2009a,b; Badarinath et al., 2010; and many others). Additionally, frequent outbreak of wildfires and the burning of agricultural waste also contribute to increased loading of LAA over South Asia during the pre-monsoon dry season (Zhang et al., 2020). As a result, abundant quantities of LAAs from both anthropogenic (industry, domestic consumption, and agricultural burning), and natural sources (dust and wildfires) build up to a thick and expansive layer over the HimalayasGangetic Plain during April-August (Gautam et al., 2010, 2011). The thick LAA layer provides an effective radiative heat source, which can trigger dynamical feedback through increased moisture and dust transport, enhanced latent heating, leading to a strengthened early monsoon via the so-called Elevated Heat Pump (EHP) feedback mechanism (Lau et al., 2006, 2008). Airborne LAA eventually falls back to the earth surface by dry and wet deposition. LAA in snow reduces the surface albedo and increases absorption of solar radiation, leading to accelerated snowmelt and warming of the surface, i.e., the snow-darkening effect. Deposition of LAAs on snow over the Himalayas-Tibetan Plateau is found to have strong impacts on the warming of the Tibetan Plateau, affecting the strength, and evolution of the ASM (Flanner and Zender, 2005; Flanner et al., 2007; Qian et al., 2009, 2015; Lau and Kim, 2018; Zhang et al., 2020).

During pre- and early monsoon, dust is by far the most dominant contributor to the atmospheric loading of LAAs affecting the Indian summer monsoon (ISM). The heating of the atmosphere by dust absorption of solar radiation over the North Arabian Sea, and Northwestern India is substantial (12.5 $\mathrm{Kday}^{-1}$ ) during March-June, exceeding by as much as 1.5-2 times the forcing due to anthropogenic aerosols during the boreal winter (Ramachandran, 2005; Moorthy et al., 2007; Pandithurai et al., 2008; Satheesh et al., 2008; Das et al., 2015). More recently, observational and modeling studies have revealed significant impacts on variability of ISM induced by Middle East dust radiative forcing (Gautam et al., 2009a; Jin et al., 2014, 2016;
Lau, 2014; Vinoj et al., 2014; Wei and Yang, 2014; Kim et al., 2015; Solmon et al., 2015). For monsoon dynamical feedback, Middle East dust is critically important because of (a) abundant transport by monsoon southwesterlies, (b) strong absorptive power due to its high content of iron-oxide (Sokolik and Toon, 1999; Alfaro et al., 2004), and (c) increased SW absorption due to coating by fine $\mathrm{BC}$ particles during passage over the densely populated regions of the ASM (Chandra et al., 2004; Prasad and Singh, 2007; Giles et al., 2012). Given the abundance of natural LAA, and their strong interactions with monsoon dynamics, it has been argued that LAA from natural sources should be considered an intrinsic component of the ASM climate system, contributing substantially to the subseasonal-to-seasonal (S2S) variability of the ASM (Lau, 2016; Li et al., 2016). Because the real climate interacts with ambient aerosols regardless of their sources, unraveling the intrinsic interactions of natural aerosol and climate is a prerequisite for better understanding of the impacts of anthropogenic aerosols on ASM. Yet, the mechanisms of interaction of LAA, in particular desert dust, with clouds, precipitation, and monsoon dynamics on S2S time scales are not well understood, and under-explored. The objective of this study is to delineate the fundamental processes that govern the interactions of LAA and ASM dynamics, from emission, transport, and radiative forcing to interactions with clouds, precipitation, convection, moisture transport, and the large-scale circulation, focusing on S2S variability of the ASM.

\section{MODEL DESCRIPTION AND EXPERIMENTAL DESIGN}

Global climate model (GCM) has been an essential tool for advancing understanding of aerosol-monsoon processes. For better simulations of climatic impacts of aerosol-precipitationconvection-circulation interactions in monsoon regions, the effects of complex topographic features such as the HimalayasTibetan Plateau are critically important and require high resolution, ensemble simulations at refined scales (30 km or less). Yet, up to now, most GCM experiments of aerosol-monsoon climate studies have been conducted with low-to-moderate resolution ( $>100-200 \mathrm{~km}$ ) GCMs, because of the prohibitive computational resources needed for high-resolution $(<30 \mathrm{~km})$ GCM simulations. As a result, the effects of complex topography such as the Himalayas foothills and Tibetan Plateau region on aerosol-precipitation-convection-circulation interactions are not adequately represented in previous studies. Regional climate models (RCMs) with higher resolutions have also been used in downscaling studies, providing more realistic simulations of 
orographic effects on convective processes and extreme weather conditions in the ASM (Leung et al., 2003; Evans, 2011). However, RCMs are generally confined to a selected limited domain, not the entire ASM and influence regions, and are also hampered by their inability to simulate two-way interactions between the regional monsoon and the global circulation. As a result, global influence of the ASM cannot be studied using RCMs.

The global variable resolution Model for Predication Across Scales (MPAS) for the atmosphere has been designed to mitigate the aforementioned shortcomings associated with GCMs and RCMs (Skamarock et al., 2012). Through the use of regional refinement enabled by the unstructured grid, MPAS has been shown to produce high resolution regional climate and weather features comparable to those simulated by the model with global quasi-uniform high resolution mesh, but at a much smaller fraction of the computational cost (Sakaguchi et al., 2015; Zhao et al., 2019). Regional refinement also allows the regional climate simulated inside the refined mesh to exert remote influences outside the high-resolution region (Sakaguchi et al., 2016). In this study, we use the non-hydrostatic version of MPAS coupled with the physics package of Community Atmosphere Model version 5 (CAM5; Neale et al., 2012). Zhao et al. (2016) compared this non-hydrostatic MPAS-CAM5 with the hydrostatic MPASCAM4 used in Sakaguchi et al. $(2015,2016)$ in a hierarchy of aqua-planet simulations (Leung et al., 2013) and reported reduced sensitivity of the non-hydrostatic MPAS-CAM5 to model resolution compared to the hydrostatic MPAS-CAM4. A variable resolution mesh has been configured for this study similar to Zhao et al. (2016). The target high resolution $(30 \mathrm{~km})$ domain is centered over the complex terrain of the Middle East/Himalayas-Tibetan Plateau/South Asian monsoon region, transitioning to a low-resolution $(120 \mathrm{~km})$ domain covering the rest of the globe (Figure $\mathbf{1}$ ).

In the CAM5 physics package coupled in MPAS, cloud microphysics is represented by the Morrison and Gettelman (2008) scheme with prognostic cloud liquid and cloud ice and cloud droplet number. For cloud macrophysics, the total cloud fraction is calculated as the sum of the stratiform and convective cloud fractions. Cumulus convection is based on the Zhang and McFarlane (1995) scheme. Shallow convection and planetary boundary layer turbulence are based on a plume dilution model and a turbulence kinetic energy scheme described in Bretherton and Park (2009). The three-mode version of the modal aerosol scheme (MAM3) used in this study features Aitken, accumulation, and coarse modes. Aerosol components are internally mixed in each mode and the mass and number concentrations in each mode are updated during the simulation (Liu et al., 2012). The model includes important processes that influence the dust life cycle such as emission, dry and wet deposition. The Community Land Model, version 4.0 (CLM4) is used in this study and the CLM4 default data for soil properties, defined on a $1.9^{\circ} \times 2.5^{\circ}$ mesh, is used for on-line calculation of dust emission fluxes. The Rapid Radiative Transfer Model for GCMs (RRTMG) is used for long-wave and shortwave radiative transfer (Iacono et al., 2000; Mlawer et al., 2016). Aerosol optical properties are calculated following Ghan and Zaveri (2007). The real component of dust refractive index varies only slightly in
near-IR wavelengths $(\sim 1.53)$, while its imaginary component varies between $-0.004 \mathrm{i}$ and $-0.03 \mathrm{i}$. Aerosol influence on stratiform cloud microphysics droplet activation and ice nucleation are based Abdul-Razzak and Ghan (2002) and Liu et al. (2007).

Except for desert dust emissions, which are controlled by internal dynamics of the atmospheric surface and boundary layer processes, as well as land surface properties and states, emissions of BC, OC, and different types of natural and anthropogenic aerosols, and GHG gases are based on the present-day emission inventory from IPCC AR5 estimates (Lamarque et al., 2010). As a first step to tease out the roles of LAAs among the many control factors [sea surface temperature (SST), teleconnections, land use and change, emissions of diverse type of aerosols, and greenhouse gases] that are known to contribute to ASM climate variability and change, we carried out AMIP-type control integration with prescribed SST for the 10-year period (2000-2009), with full (both natural and anthropogenic) emission of LAAs (FEM). An identical experiment, except with the total LAA emissions cut by half (HEM) was carried out. The impacts of LAAs on ASM climate will be evaluated based on differences of key quantities between FEM and HEM (FEM-minus-HEM), hereafter referred to as "anomalies." Thus, the anomalies reflect the impact of increased LAA emissions and loading.

\section{RESULTS}

To begin our analysis, we examine the MPAS simulated aerosol and monsoon climatology, compared to observations. The simulated June-July-August (JJA) mean rainfall and $850 \mathrm{hPa}$ winds show a reasonable distribution compared to MERRA2 reanalysis and TRMM, respectively, (Figures 2A,B), showing strong cross-equatorial Somali jet, prevailing southwesterlies over India/Southeast Asia, and southerlies over China. The model rainfall for the ISM shows fine structure associated with topography, including maximum rainfall over the western Ghats, the Himalaya foothills, and northeastern India. However, MPAS rainfall over the Bay of Bengal is deficient compared to TRMM. For the East Asian summer monsoon (EASM), both model and observation show that the seasonal mean rainfall is much weaker and less regionally confined compared to ISM, due to the strong influence of the subtropical jet, and larger variability in the locations of the EASM Mei-yu rain belt (Lau and Li, 1984; Lau et al., 2000; Ding and Chan, 2005; Wang, 2006; Zhang et al., 2006; Wang, 2009). Compared to TRMM, the model EASM rainfall is also under-estimated. For AOD, the model shows excessive dust loading over the source region near Middle East/northern Arabian Sea, northwestern Asia/eastern Eurasia, and the Taklamakan desert, compared to MODIS (Figures 2C,D). Over the Indian subcontinent, the Bay of Bengal/Southeast Asia, and Indo-Pacific oceanic regions, the model AOD is much weaker than MODIS. These suggest a more regional confined aerosol distribution in MPAS-CAM5 compared to MODIS, probably related to inadequate resolution of dust size distributions, and/or excessive dry and wet removal of aerosols, commonly found in numerous state-of-the-art climate models (Zender et al., 2003; Huneeus et al., 2011; Kok, 2011; Evan et al., 2014; Pan et al., 

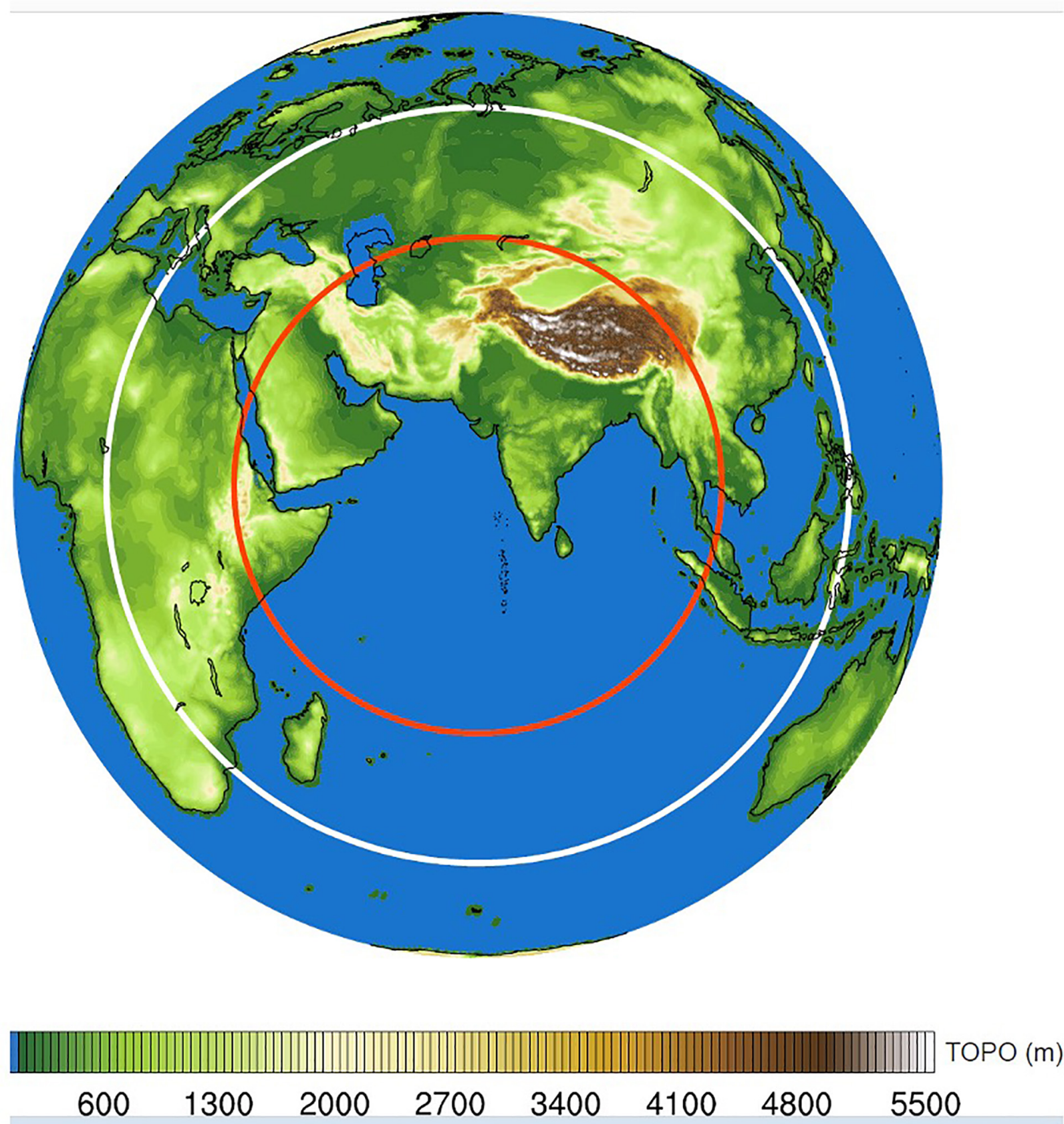

FIGURE 1 | Variable domain configuration in the MPAS experiments, with the highest resolution (25 km) centered over the target region of the Middle East desert and Indian monsoon region (inside red circle), transition via a buffer zone (between red and white circles) to the global domain with $110 \mathrm{~km}$ coarse resolution (outside the white circle).

2015). Possible implications of these model biases on the results are discussed in the "Conclusion" section.

\section{AOD, Clouds, Precipitation and Circulation Changes}

In this subsection, we examine the mean JJA anomaly patterns of AOD, temperature, moisture, clouds, and the large-scale circulation, respectively, over the desert-ASM domain, induced by the change in emissions of LAAs, based on the differences (FEM-minus-HEM) of these quantities. The AOD anomaly pattern (Figure 3A) shows clearly the dominance of dust forcing, featuring increased AOD over the Middle East desert regions, and the Taklamakan Desert over northwestern China, consistent with the experimental design (see section "Model description and experimental design"). In response, the land 

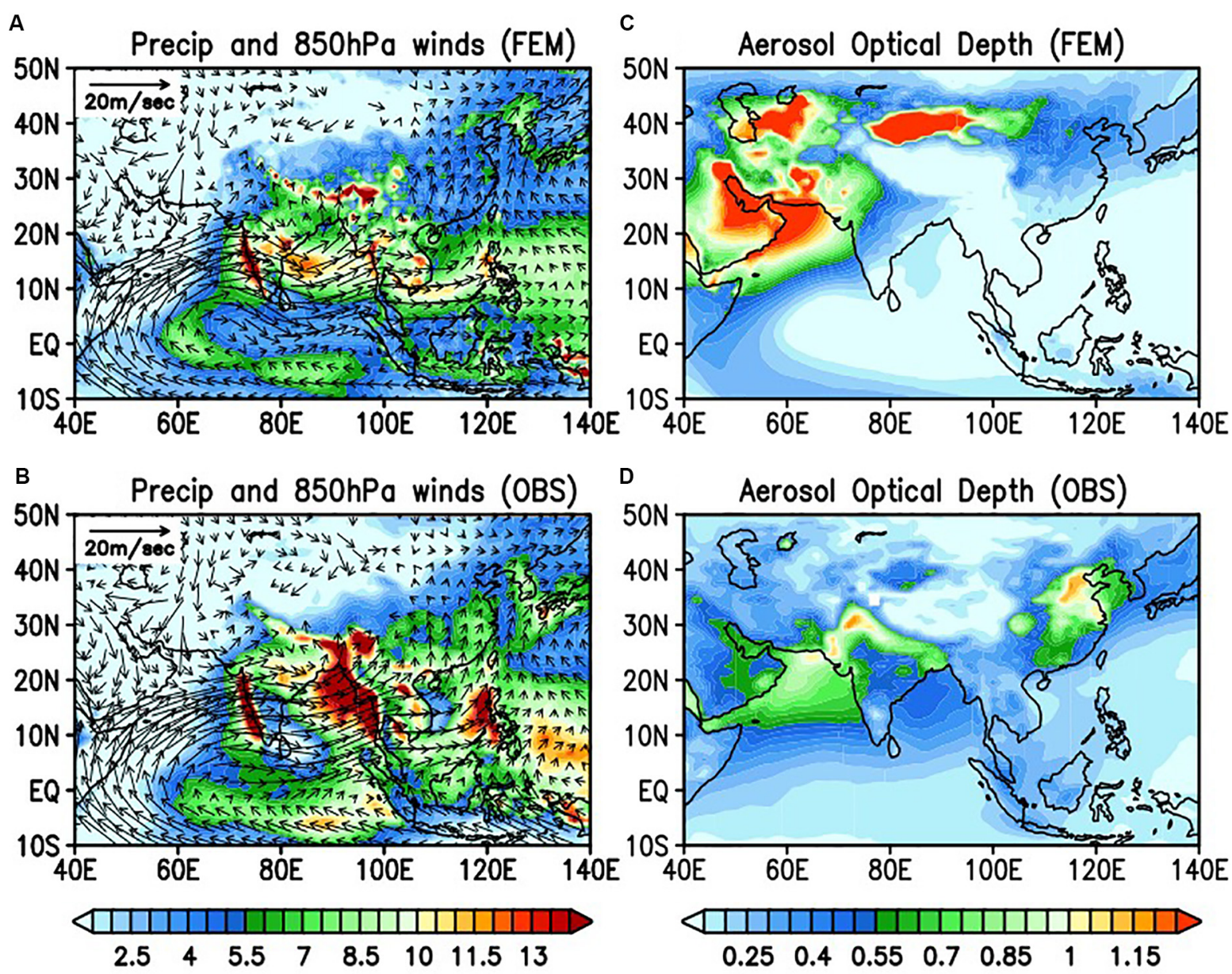

FIGURE 2 | Climatological distribution of precipitation $\left(\mathrm{mm}^{\text {day }}{ }^{-1}\right)$ and $850 \mathrm{hPa}$ winds $\left(\mathrm{ms}^{-1}\right)$ for (A) MPAS simulations based on present-day aerosol emission inventory and full dust emission (FEM), with prescribed sea surface temperature (2001-2010), and (B) observations from TRMM and MERRA2 reanalysis (2001-2010). (C,D) Shows respectively AOD simulated by MPAS, and from MODIS satellite retrievals.

surface is cooled over the Middle East desert, the Tibetan Plateau, and northwestern India, and warmed over northern, and eastern Asia (Figure 3B). Anomalous warming of the lower and mid-troposphere is found over the desert and arid regions, centered around the Iran/Pakistan/West Himalayas region (Figure 3C). The tropospheric warming is mostly zonally oriented, spanning eastern Europe, central Asia to northeastern East Asia and appears to be coupled to an extensive zonally oriented cooling region over southern East Asia. Significant increase in cloudiness is found over the West Asia/Middle East region, the climatological arid region of Central Asia, and PNWI, accompanied by decreased cloudiness over East Asia and northwestern China (Figure 3D).

Seasonal mean (JJA) precipitation is increased over PNWI, in conjunction with the development of a cyclonic circulation cell over northwestern India, coupled to an anticyclonic cell over southern India and the Indian Ocean (Figure 4A). This circulation couplet strengthens the westerly moisture transport from the Arabian Sea to northwestern and western India and increases northward moisture transport from the North Arabian
Sea to PNWI. As will be shown later (see Figure 5), the increased moisture transport to the PNWI leads to enhanced moisture convergence and cloudiness, which in turn increases shielding of solar radiation, and thus reduces the land surface temperature locally (see Figure 3B). Anomalous low-level easterlies are found near $15-25^{\circ} \mathrm{N}$, spanning the western Pacific/South China Sea across Indo-China and PNWI. This curtails the climatological southwesterly moisture transport from the Bay of Bengal and northern India, to East Asia, resulting in suppressed precipitation and reduced cloudiness over central and southern China. The changes in precipitation, clouds and low-level winds are associated with the development of an upper tropospheric Rossby wavetrain spanning the subtropics and mid-latitudes of Eurasia, the Tibetan Plateau and East Asia. The wavetrain is likely the result of interaction of the upper tropospheric mean flow and a Rossby wave generated by the increased latent heating over PNWI region, and interaction with the jetstream (Rodwell and Hoskins, 1995). Here an elongated dipole anomaly in zonal winds at $200 \mathrm{hPa}$ is found signaling a poleward shift of the jetstream that spans the Middle East, eastern Europe/central 

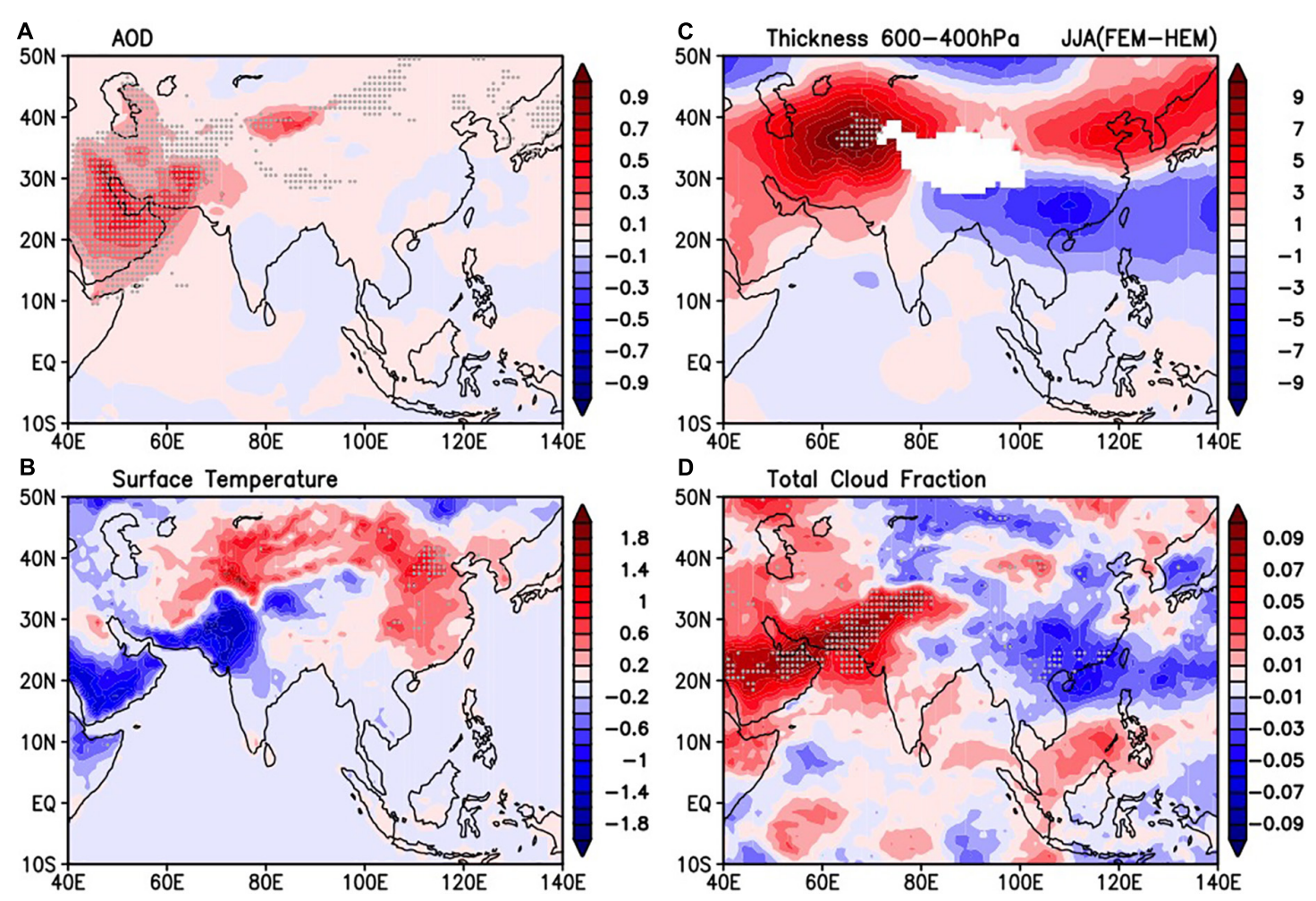

FIGURE 3 | MPAS simulated JJA anomalies in (A) AOD, (B) surface temperature ( $\left.{ }^{\circ} \mathrm{C}\right)$, (C) $600-400 \mathrm{hPa}$ (gpm) thickness, and (D) cloud fraction. Anomalies are defined as the difference between FEM (full LAA emission) and HEM (half LAA emission).

Asia and East Asian regions, coupled to increased westerlies (reduced climatological upper level easterlies) over the southeast Asia/western Pacific region (Figure 4C). Figure 4D shows that the circulation changes reflect, in part, a westward shift of the West Pacific Subtropical High (WPSH), and a slightly weakened and contracted climatological South Asian High (SAH) consistent with reduced precipitation over southern and central East Asia (Lau and Li, 1984; Ding and Chan, 2005; Wang, 2006). Summing up, it can be inferred from results presented so far that increased LAA emission can lead to changes in major large-scale controls of the ASM, i.e., the WPSH, the SAH and the upper level jetstream spanning eastern Europe and East Asia.

\section{Aerosol-Cloud Radiation, and Circulation Feedback}

The roles of radiative forcing by LAAs and induced dynamical feedback of the coupled desert-ASM system are examined in this subsection. Over the desert and semi-arid regions $\left(15-35^{\circ} \mathrm{N}, 40-\right.$ $70^{\circ} \mathrm{E}$ ), the model LAAs consist of mostly dust (Figure 5A). Note that the concentration of dust by mass is in units of $\mathrm{mg} / \mathrm{kg}$, three order of magnitude more abundant than BC $(\mu \mathrm{g} / \mathrm{kg})$. The dust concentration is highest near the surface, but with significant concentration extending to the lower troposphere $(\sim 600 \mathrm{hPa})$ and above. Over the desert and ISM region, the land surface and atmospheric boundary layer are cooled due to the blocking of downward SW by dust and BC, i.e., the solar dimming effect (Ramanathan et al., 2005). On the other hand, above the boundary layer, the troposphere is warmed by the SW absorption by dust. The warm above/cool below anomaly profile increases local atmospheric stability, i.e., the semi-direct effect (Hansen et al., 1997; Lohmann and Feichter, 2001), which tends to suppress convection. However, the warmer dust layer increases the low-to-mid troposphere meridional temperature gradient between the desert and the Arabian Sea to the south, thus enhancing the northward and westward transport of moisture from the North Arabian Sea to the land regions to the north (see Figure 4A). This can be seen in the deep layer of moist (high specific humidity) air over the desert/PNWI region (60$80 \mathrm{E}$; Figure 5C). Together with the warming, this means a large increase in moist static energy $\left(\mathrm{C}_{p} \mathrm{~T}+\mathrm{Lq}\right)$ and convective potential (Figure 5B). As the monsoon season advances, the increase in convective potential eventually overcomes the local solar dimming and semi-direct stabilizing effects through LAA induced dynamical feedback, resulting in increased latent heating over the desert and semi-arid regions (Figure 5C), most pronounced over the foothills of PNWI $\left(70-80^{\circ} \mathrm{E}\right)$, and reduced latent heating over East Asia $\left(100-120^{\circ} \mathrm{E}\right)$. For energy balance, large-scale circulation adjustments take place, with anomalous rising motions (adiabatic cooling) over the desert regions and sinking motions (adiabatic warming) connecting the desert/ISM and the EASM domain. The anomalous circulation redistributes clouds and precipitation over the entire desert-monsoon system, resulting in a warmer/wetter/more cloud desert and western 

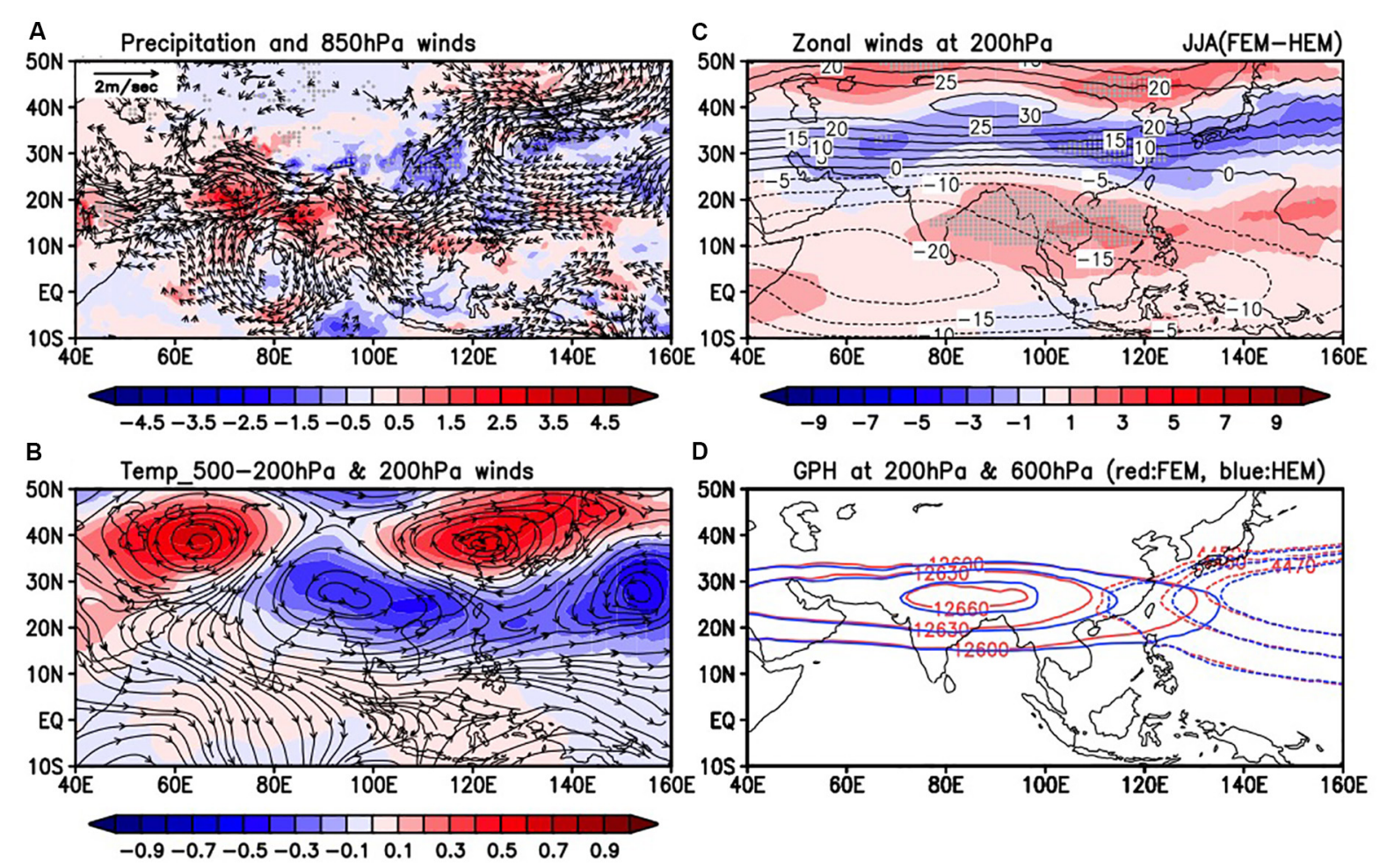

FIGURE 4 | MPAS simulated JJA anomalies in (A) precipitation ( $\mathrm{mm}$ day $\left.{ }^{-1}\right)$ and $850 \mathrm{hPa}$ winds $\left(\mathrm{ms}^{-1}\right)$, (B) average temperature between 500 and $200 \mathrm{hPa}(\mathrm{K})$, and $200 \mathrm{hPa}$ winds (stremalines), (C) $200 \mathrm{hPa}$ anomalous (colored) and climatological zonal winds (contoured), and (D) geopotential heights contours showing displacement of the SAH (200 hPa), and the North Pacific Subtropical High (600 hPa) due to changes in LAA radiative forcing from HEM (blue) to FEM(red).

ISM, and colder upper troposphere over the Tibetan Plateau (Figure 5B), coupled to a cooler/drier/less cloudy EASM. Over the desert/ISM domain, the meridional wind profile shows northerlies (negative anomalies) at upper levels in regions of increased high clouds, and southerlies (positive anomalies) in the lower troposphere, coupled to anomalies of opposite signs over the EASM domain (Figure 5D). These features represent regional manifestations of a contraction of the $\mathrm{SAH}$ and westward displacement of the WPSH (see Figure 4D), that are consistent with approximate vorticity balance governing thermally driven Rossby wave, circulation divergence, and zonal mean flow in a $\beta$ plane (Gill, 1980; Lau and Lim, 1982; Lau et al., 2000). Further discussion of Rossby wave-mean flow interaction is provided in section "Wavetrain-jetstream interactions."

Since the increase in moisture over the desert/PNWI region (Figure 5B) is instrumental to the enhanced diabatic heating (Figure 5C) and subsequent changes in circulation and cloud fraction over an expansive region reaching East Asia, it is important to elaborate on the role of dust radiative forcing and cloud feedback in establishing the anomalous profile of temperature and moisture in the desert/PNWI region shown in Figure 5B. The strong radiative forcing by desert dust can be seen in the anomalous clear sky radiative forcing, indicating strong TOA radiative warming of the atmosphere-land system, over the Middle East, and PNWI region (Figure 6A) due to increased dust emission. Overall the atmosphere is warmed, and the surface is cooled (Figures 6B,C), due to the semi-direct effect. However, in the Middle East and PNWI (Figure 6C), the land surface is also warmed due to downwelling longwave radiation, as well as multiple reflection of sunlight by dust (Solmon et al., 2008; Xia and Zong, 2009; Gautam et al., 2010; di Sarra et al., 2011). The all-sky radiative forcing shows that cloud feedback plays an important role in expanding the regions of TOA radiative forcing over East Asia (Figure 6D, compared to 6A), enhancing and expanding regions of atmospheric heating and cooling (Figure 6E, compared to 6B). Notice that cloud radiative forcing has the largest effect at the surface, enhancing and expanding the surface cooling over the Middle East desert regions, and surface warming over East Asia (Figure 6F compared to 6E) due to reduced cloudiness (see also Figures 3B,D).

A breakdown of the clear-sky radiative forcing over land regions of the western domain $\left(40-75^{\circ} \mathrm{E}, 10-35^{\circ} \mathrm{N}\right)$ that includes the Middle East desert and PNWI, into shortwave (SW) and longwave (LW) radiation at TOA, ATM, and SFC (Table 1A), indicates that strong heating of the atmosphere $\left(+7.6 \mathrm{Wm}^{-2}\right)$, and cooling $\left(-8.1 \mathrm{Wm}^{-2}\right)$ of the surface due to SW semidirect effect. However, while dust cools the atmosphere by LW radiation, it also contributes to land surface warming by downward longwave radiation (Huang et al., 2009; Zhao et al., 2016). As a result, the net effect of LAAs, as evident in the clear-sky total radiative (SW + LW) forcing is to warm both the atmosphere $\left(2.9 \mathrm{Wm}^{-2}\right)$, and the land surface 


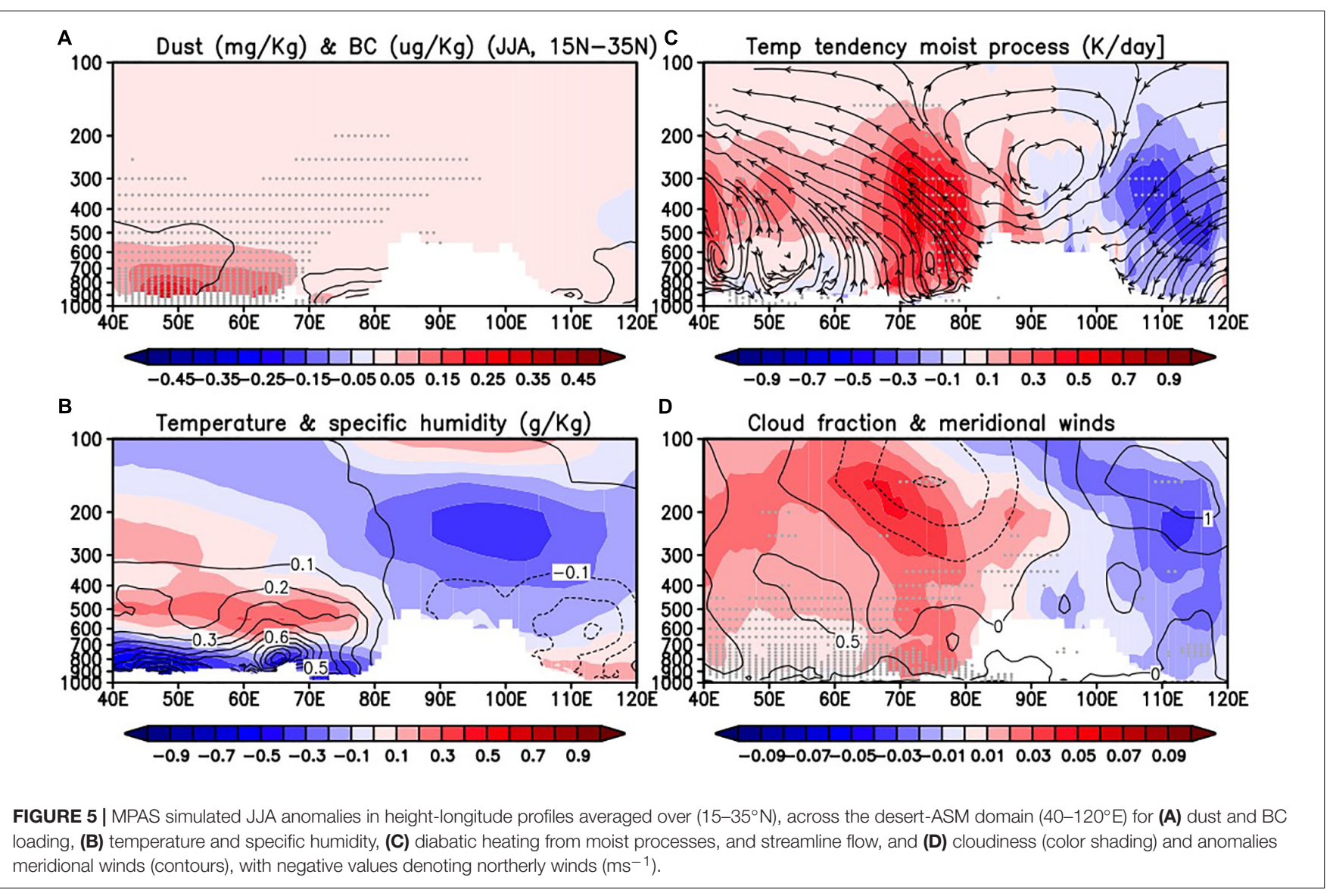

$\left(1.5 \mathrm{Wm}^{-2}\right)$. These suggest that, in spite of the semi-direct effect cooling the surface, and increasing stability in the pre-monsoon season, enhanced radiative warming of the dust layer in lower troposphere over the desert region due to more dust emission is instrumental in increasing the meridional temperature gradient in the lower troposphere, and eventually leads to enhanced moisture transport, moisture convergence and precipitation over the northern PNWI.

In the presence of cloud feedback, as shown in the all-sky radiative forcing, the SW surface cooling is strongly enhanced $\left(-13.4 \mathrm{Wm}^{-2}\right)$ due to shielding by the increased cloudiness over the region (see Figure 3D). However, LW cooling of the atmosphere is much reduced $\left(-1.6 \mathrm{Wm}^{-2}\right)$ from the clear-sky values $\left(-4.7 \mathrm{Wm}^{-2}\right)$ due to trapping of $\mathrm{LW}$ by increased water vapor and clouds. This results in a net radiative heating of the atmosphere $\left(+5.7 \mathrm{Wm}^{-2}\right)$, almost double the clear-sky value $\left(+2.9 \mathrm{Wm}^{-2}\right)$, while inducing a net cooling $\left(-3.2 \mathrm{Wm}^{-2}\right)$ at the land surface, due to increased cloud shielding. This is the underlying reason for the presence of the shallow cooling air layer over land, overlain by a warmer tropospheric layer above (see Figure 5B). The increased heating of the dust layer enhances the meridional thermal gradient of the lower troposphere between the desert and the North Arabian Sea, facilitating the northward transport of moisture. The enhanced moisture near the surface, and in the planetary boundary layer increases the moist static energy, allowing convection to eventually break through the stability constraint by the local semi-direct effect, as the monsoon season advances. Hence clouds play an important role in enhancing the radiative heating in the dust layer, promoting moisture transport into the dust region, which further amplifies the cloud response in a cloud feedback loop.

Over the eastern domain $\left(20-40^{\circ} \mathrm{N}, 75-120^{\circ} \mathrm{E}\right)$ which covers most the EASM region, the clear-sky radiative forcing is much smaller $\left(<1 \mathrm{Wm}^{-2}\right)$, and less consequential, compared to the western domain. This is consistent with the much lower model AOD over the region (Figure 1C). Here, the reduced cloudiness (see Figure 3D) consistent with the suppressed precipitation (see Figure 4A) contributes to the warming of the land, by increasing surface downward SW $\left(+2.2 \mathrm{Wm}^{-2}\right)$, resulting in a net radiative warming of the surface $\left(+1.7 \mathrm{Wm}^{-2}\right)$. Given the much smaller values of the clear sky SW and LW forcing over the eastern compared to the western domain, it may be inferred that strong aerosol radiative forcing is restricted to the western (desert) domain, and that changes in EASM rainfall are due largely to dynamically induced circulation-cloud radiation feedback processes.

\section{S2S Variability}

The physical processes governing the atmospheric loading and radiative forcing of LAAs are strongly dependent on winds and precipitation and are therefore closely linked to intrinsic monsoon S2S variability. Here the monthly evolution of various 


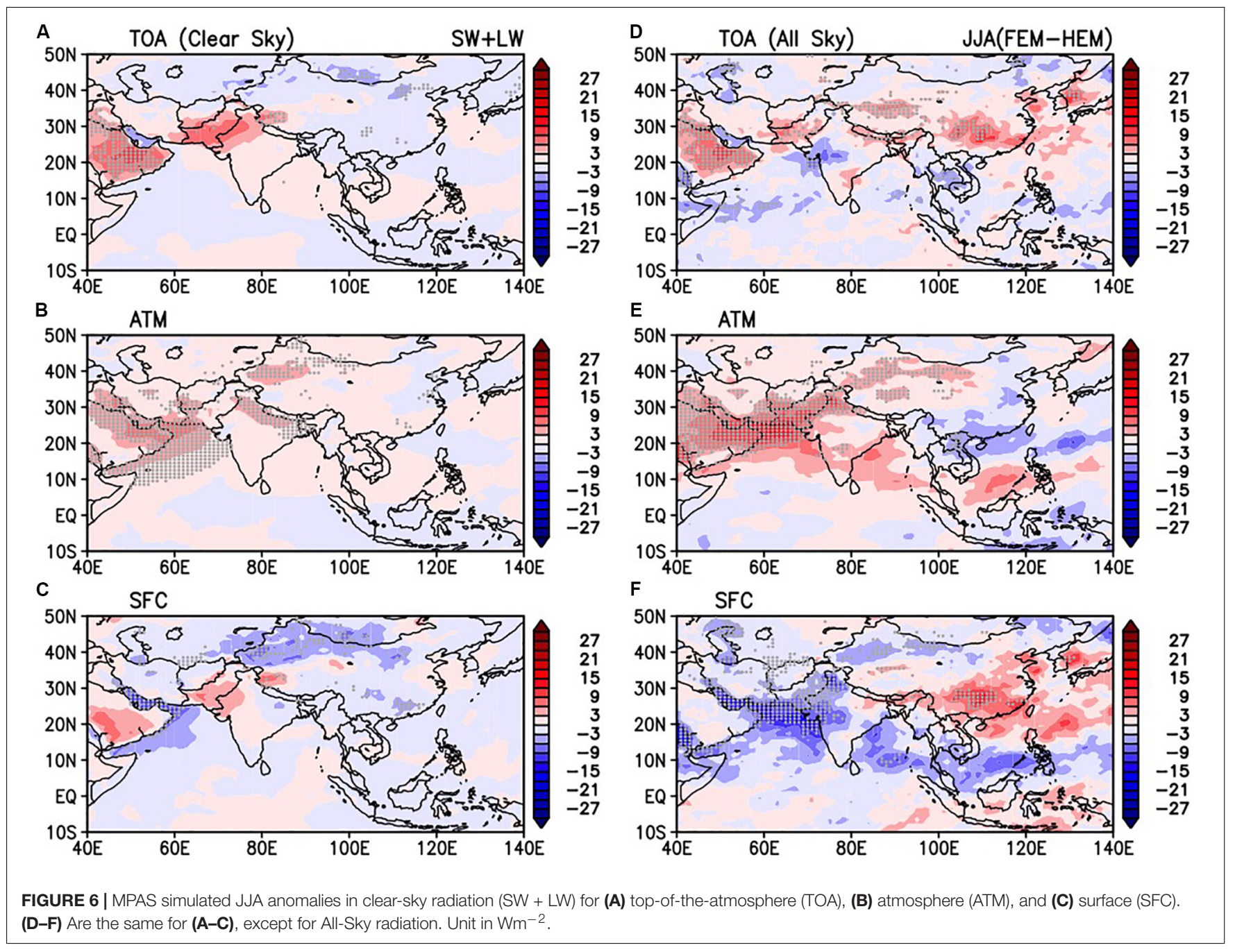

TABLE 1 | Clear sky, and all-Sky radiation anomalies $\left(\mathrm{Wm}^{-2}\right)$ for JJA, at top of the atmosphere (TOA), over the atmospheric column (ATM), and at the surface (SFC) for the land regions of $(\mathbf{A})$ the western domain $\left(40-75^{\circ} \mathrm{E}, 10-35^{\circ} \mathrm{N}\right)$ that include the Middle East desert, western India, and (B) the eastern domain $\left(75-120^{\circ} \mathrm{E}, 20-40^{\circ} \mathrm{E}\right)$ covering northeastern India and the East Asian region. JJA (Land only).

\begin{tabular}{|c|c|c|c|c|c|c|}
\hline & \multicolumn{3}{|c|}{ Clear sky } & \multicolumn{3}{|c|}{ All sky } \\
\hline & sw & LW & sW + LW & sw & LW & $S W+L W$ \\
\hline TOA & $-0.5 \pm 0.70$ & $4.8 \pm 0.87$ & $4.4 \pm 1.52$ & $-6.0 \pm 1.12$ & $8.6 \pm 2.21$ & $2.6 \pm 1.14$ \\
\hline SFC & $7.6 \pm 0.57$ & $-4.7 \pm 0.56$ & $2.9 \pm 0.80$ & $7.4 \pm 0.54$ & $-1.6 \pm 0.83$ & $5.7 \pm 0.85$ \\
\hline ATM & $-8.1 \pm 1.09$ & $9.5 \pm 1.33$ & $1.5 \pm 2.17$ & $-13.41 \pm 1.14$ & $10.2 \pm 1.59$ & $-3.2 \pm 0.91$ \\
\hline ATM & $1.1 \pm 0.27$ & $-0.1 \pm 0.47$ & $1.0 \pm 0.43$ & $0.8 \pm 0.35$ & $-0.2 \pm 0.61$ & $0.6 \pm 017$ \\
\hline SFC & $-1.1 \pm 0.46$ & $-0.0 \pm 0.81$ & $-1.1 \pm 1.11$ & $2.2 \pm 2.38$ & $-0.5 \pm 1.25$ & $1.7 \pm 120$ \\
\hline
\end{tabular}

changes induced by LAAs is investigated. During April-May, AOD is substantially increased over the Middle East deserts due to the doubling of emissions, from the experimental design. Over the Indo-Gangetic Plain and northern India, AOD is increased (Figure 7A, for May) stemming from the transport by the strengthening monsoon seasonal southwesterlies. At this time, the land surface of the desert and Indian subcontinent is cooled due to AOD SW shielding, while SW absorption by the dust layer heats the lower troposphere (see Figure 8C, later). This increases atmospheric stability, i.e., the semi-direct effect, 
resulting in reduced vertical heat transport from the boundary layer to the free atmosphere, and anomalous cooling of the midtroposphere (Figure 7E), as well as reduced precipitation over the desert, the Indian subcontinent, and adjacent oceanic regions (Figure 7I).

As the monsoon season advances, AOD loading remains strong over Middle East deserts and downstream regions from June-August due to enhanced dust emission, and transport by the strengthening seasonal westerly low-level winds. However, the AOD increase is mostly confined to the deserts and PNWI, but less pronounced over the rest of the India subcontinent and adjacent oceans during (Figures $7 \mathbf{B}-\mathbf{D}$ ), due to removal by wet deposition and washout from increased precipitation (Figures 7J-L). During June, the troposphere over the land regions north of the Arabian Sea is anomalously warmer compared to regions to the south (Figure 7F) due to induced dust-cloud-radiation-circulation feedback (see later discussion for Figure 8 for details). This leads to the development of a low-level cyclone over PNWI, and increased precipitation across northwest and central India, with increased low-level westerlies, transporting moisture from the Arabian Sea, and the equatorial Indian Ocean to the Indian subcontinent (Figure 7J). The tropospheric warming over the land north of the Arabian Sea maximizes over the western Himalayas//Iranian Plateau (WHIP) region in July and August (Figures 7G,H). In July, the PNWI cyclone is somewhat weakened, with increased precipitation spread over central India and the southern Bay of Bengal, and increased low level westerlies is confined to southern Arabian Sea (Figure 7K). In August (Figure 7L), the cyclonic cell is re-established, and precipitation is re-invigorated over PNWI. These reflects enhanced S2S variability of the ISM.

The topography of the WHIP region $\left(25-35^{\circ} \mathrm{N}, 60-75^{\circ} \mathrm{E}\right)$ plays an important role in the aforementioned dust-induced dynamical feedback processes. During May-June, dust aerosols from local emission and transported from the Middle East deserts accumulate over the southern slopes of the WHIP and land region to the south, and get lofted to the midand upper troposphere, by orographically forced ascent and local convection (Figures 8A,B,E,F). BC from prescribed local emission is also increased (doubled by the experimental design) in the southern foothills of WHIP. Strong SW heating (0.2$0.4 \mathrm{~K} \mathrm{day}^{-1}$ ) is found in the lower and mid-troposphere over the WHIP foothills, and northern Arabian Sea, near $10-35^{\circ} \mathrm{N}$ (Figures 8C,G). Judging from the similar spatial distributions of the SW heating and dust burden, it is evident that the SW heating is due mostly to dust. This is so even though BC is highly absorbing, due to its much lower atmospheric burden compared with dust, and limited spatial distribution. During May-June, the dust SW heating induces a dynamical feedback that increases the tropospheric thermal land-sea contrast, strengthening the early monsoon, consistent with EHP effect (Lau et al., 2006, 2008). The time-delayed effect of EHP, i.e., building up of convective potential against the local stabilizing effect of dust, and eventually breaking out of deep convection, is evident in the transition from reduced precipitation in May to increased precipitation in
June over the region (Figures $\mathbf{8 D}, \mathbf{H}$ ). An analysis of the daily accumulated rainfall shows that the EHP feedback advances the monsoon rainy season for ISM by about 1-2 weeks and slightly delays that for EASM by approximately 1 week (Supplementary Figure S1).

As the monsoon matures during July-August, the anomalous warming of WHIP in the mid- and upper troposphere intensifies, further enhancing the tropospheric meridional thermal gradient, and ascent near $20-30^{\circ} \mathrm{N}$ (Figures $8 \mathbf{I}, \mathbf{M}$ ). At this time, accumulation and loading of dust and BC and associated SW heating over WHIP foothills are substantially reduced (Figures 8J,N) due to wet removal by increased precipitation (Figures 8L,P). Enhanced SW heating is found in the upper troposphere (Figures $\mathbf{8 K}, \mathbf{O}$ ), stemming from absorption by increased high clouds associated with enhanced deep convection and ice-phase precipitation (see Supplementary Figure S2). The increased high clouds also cause strong SW cooling near the surface and the lower troposphere in August (Figure 8O), due to SW cloud shielding effects (Ramanathan and Collins, 1991; Lau et al., 2019). Essentially, the tropospheric temperature contrast forced by dust radiative heating during the early monsoon season is amplified and sustained through cloud radiation-precipitation-circulation feedback, affecting the entire ASM monsoon. However, as noted in the month-to-month variations of precipitation over PNWI (Figures 8D,H,L,P), and related quantities, the changes are not monotonic, but rather exhibiting amplitude modulation from May through August.

\section{Wavetrain-Jetstream Interactions}

In this section, we examine the roles of dust radiativeprecipitation-circulation feedback processes in modulating the wavetrain-jetstream interactions affecting S2S variability of the ASM. The interaction of diabatic heating, Rossby wavetrain and jetstream, giving rise to characteristic planetary scale features in the upper troposphere are well known (Hoskins and Ambrizzi, 1993; Rodwell and Hoskins, 1995; Enomoto et al., 2003; Sato and Takahashi, 2003). Previous observational studies have unveiled a family of upper tropospheric teleconnection patterns with different flavors that can affect the boreal summer regional ASM variability from subseasonal to interdacadal time scales. These include among others, the Asian-North American (ANA) pattern, the Europe-Asia (EA) pattern, the Silk Road Pattern (SRP), the jet meridional displacement (JMD), and the circumglobal teleconnection (CGT; Lau and Weng, 2002; Lu et al., 2002; Enomoto, 2004; Wakabayashi and Kawamura, 2004; Ding and Wang, 2005, 2007; Song et al., 2013; Du et al., 2016; Hong and Lu, 2016; Wang et al., 2017; Stephan et al., 2018; Xue and Chen, 2019; and others).

In the extended domain (Figure 9A), the Rossby wavetrain at $200 \mathrm{hPa}$ is clearly seen in the anomalous winds spanning the entire boreal summer jetstream region from Central to East Asia and the western Pacific $\left(25-45^{\circ} \mathrm{N}, 40-160^{\circ} \mathrm{E}\right)$. The western portion of the wavetrain $\left(C_{1}-A_{1}-C_{1}\right)$ is oriented in a NW-SE direction, across the jet axis $\left(\sim 40^{\circ} \mathrm{N}\right)$ from eastern Europe to northern India, while the eastern portion $\left(\mathrm{A}_{2}-\mathrm{C}_{2}\right)$ 


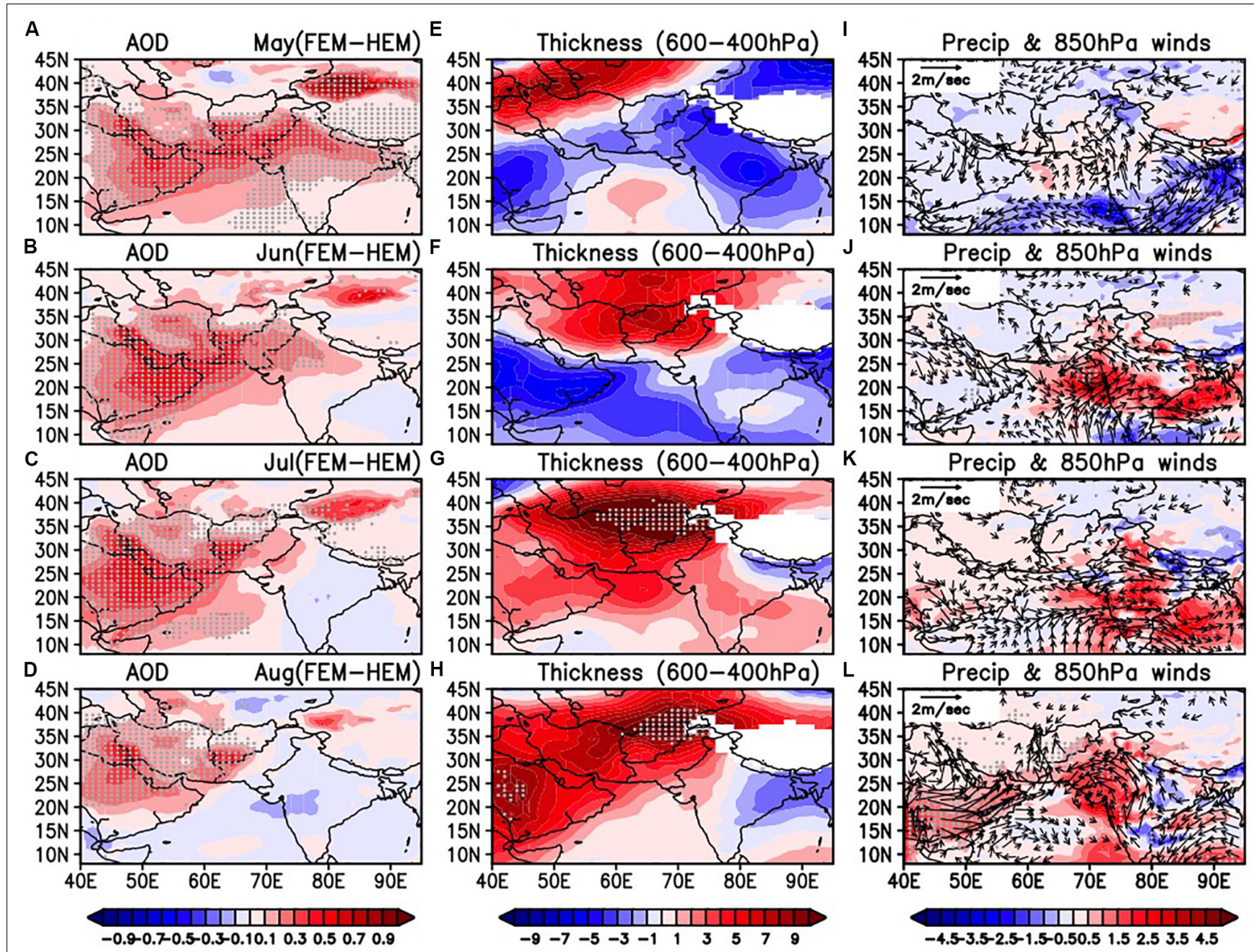

FIGURE 7 | Simulated monthly variation over the desert-ISM domain for anomalous AOD in (A) May, (B) June, (C) July, and (D) August. Panels (E), (F), (G), and (H) are the same as (A), (B), (C), and (D), except for 600-400 hPa geopotential thickness (gpm). Same for Panels (I), (J), (K), and (L), except for precipitation $\left(\mathrm{mm}\right.$ day $\left.^{-1}\right)$ and $850 \mathrm{hPa}$ winds $\left(\mathrm{ms}^{-1}\right)$.

appears to be oriented along and slightly south of the jet axis. Most prominent are two anomalous anticyclone-cyclone pairs found near the jet entrance and exit regions, respectively. For the former, the anticyclone $\left(A_{1}\right)$ is located northwest of the maximum precipitation heating over PNWI, consistent with thermally forced upper level Rossby wave by latent heating (Gill, 1980). Likewise, the cyclone $\left(C_{1}\right)$ over the Tibetan Plateau is dynamically consistent with cooling of the upper troposphere over the Tibetan Plateau (see Figure 5B) the contraction of the $\mathrm{SAH}$, and reduction in precipitation over central and southern East Asia noted earlier (see Figures 4A,D). Over eastern East Asia and the western Pacific, the anticyclone-cyclone pair $\left(A_{2}-C_{2}\right)$ reflects the signature of upper level wave-mean flow interaction, associated with the northward shift of the jetstream, and westward displacement of the WPSH.

In conjunction with the Rossby wavetrain development, there is a northward shift of the jetstream (Figure 9B, see also Figure 4C). Here, we also note that the jetstream shift is associated with east-west elongated bands of surface cooling of the Middle East desert/PNWI, warming of Central Asia/Western China, and cooling further north. This anomalous surface temperature pattern is consistent with thermal wind balance, related to changes in zonal wind vertical shear (Holton, 1993). The surface cooling (warming) pattern corresponds to increased (decreased) cloudiness, and reduced (increased) net surface SW (Figures 9C,D), across the entire domain, indicating the importance of the cloud shielding effect in modulating the land surface temperature anomalies, and jetstream wind changes. The strong anomalous upper level northerlies near $\left(25-35^{\circ} \mathrm{N}, 70\right.$ $\left.80^{\circ} \mathrm{E}\right)$, and southerlies at $\left(25-35^{\circ} \mathrm{N}, 90-110^{\circ} \mathrm{E}\right)$ in Figure $9 \mathrm{~A}$, correspond to the anomalous upper level meridional winds in the vertical wind profiles, respectively, over the Middle East-West India, and the East Asian domain, and cooling over Tibetan Plateau associated with the contraction of the $\mathrm{SAH}$, and the westward displacement of the WPSH (see discussion for Figures 5C,D). An analyses of the interaction 

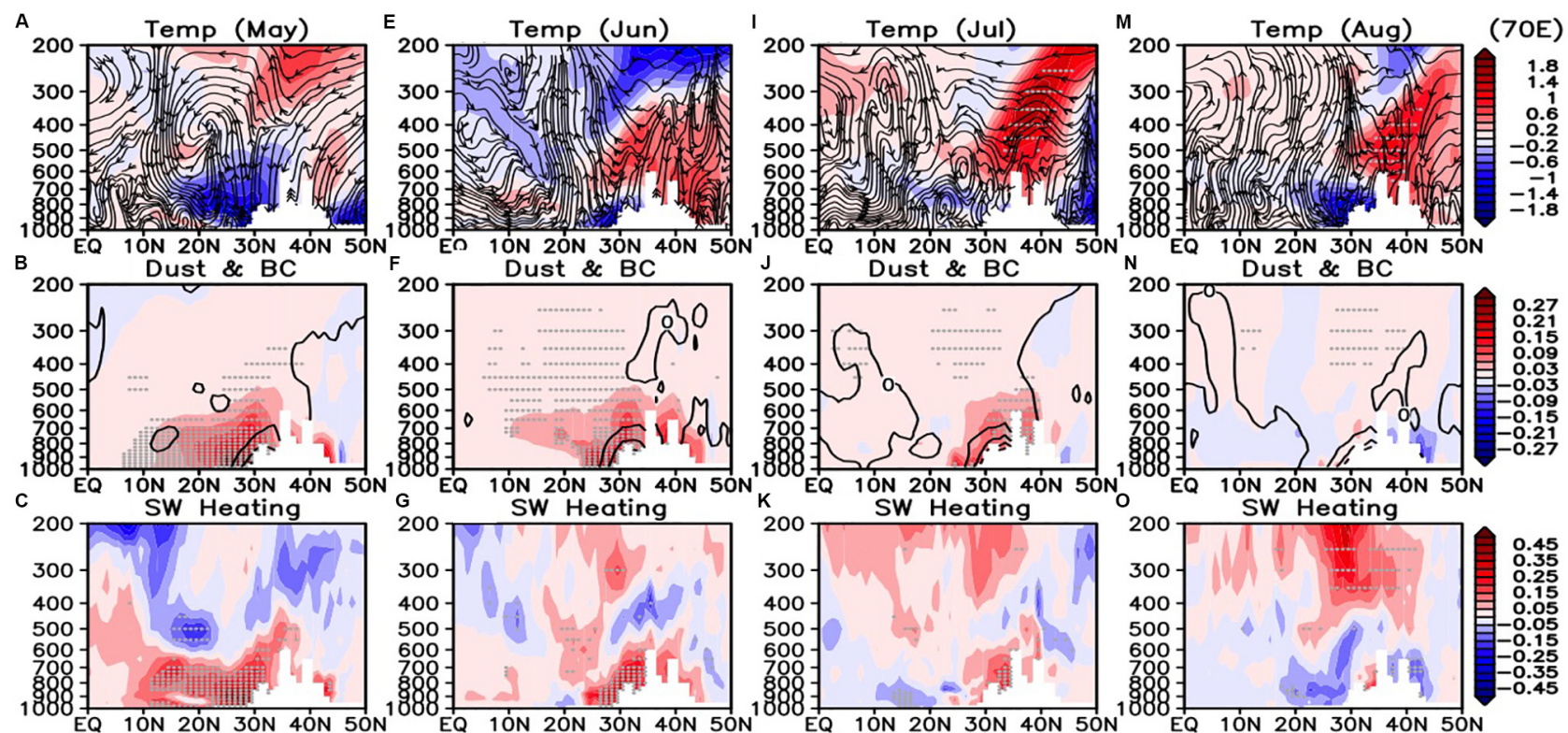

D
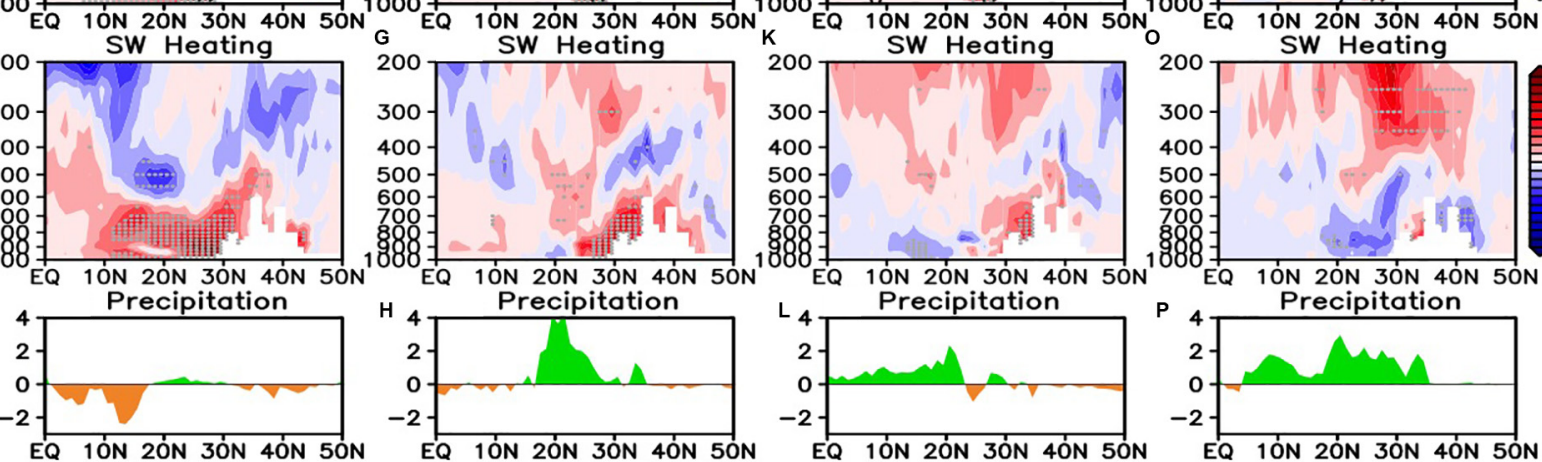

FIGURE 8 | Simulated vertical-latitude cross-sections at 70 E for anomalies in (A) tropospheric temperature and v-w streamlines, (B) atmospheric loading of dust (color shading) in $\mathrm{mg} / \mathrm{kg}$ and $\mathrm{BC}$ (contour) um/Kg, (C) shortwave heating $\left({ }^{\circ} \mathrm{C}\right.$ day ${ }^{-1}$ ), and corresponding changes in (D) anomalous precipitation (mm day $\left.{ }^{-1}\right)$. Panels (E), (F), (G), and (H) are the same as (A), (B), (C), (D), and except for June. Likewise, panels (I), (J), (K), and (L) are for July, and (M), (N), (O), and (P) for August.
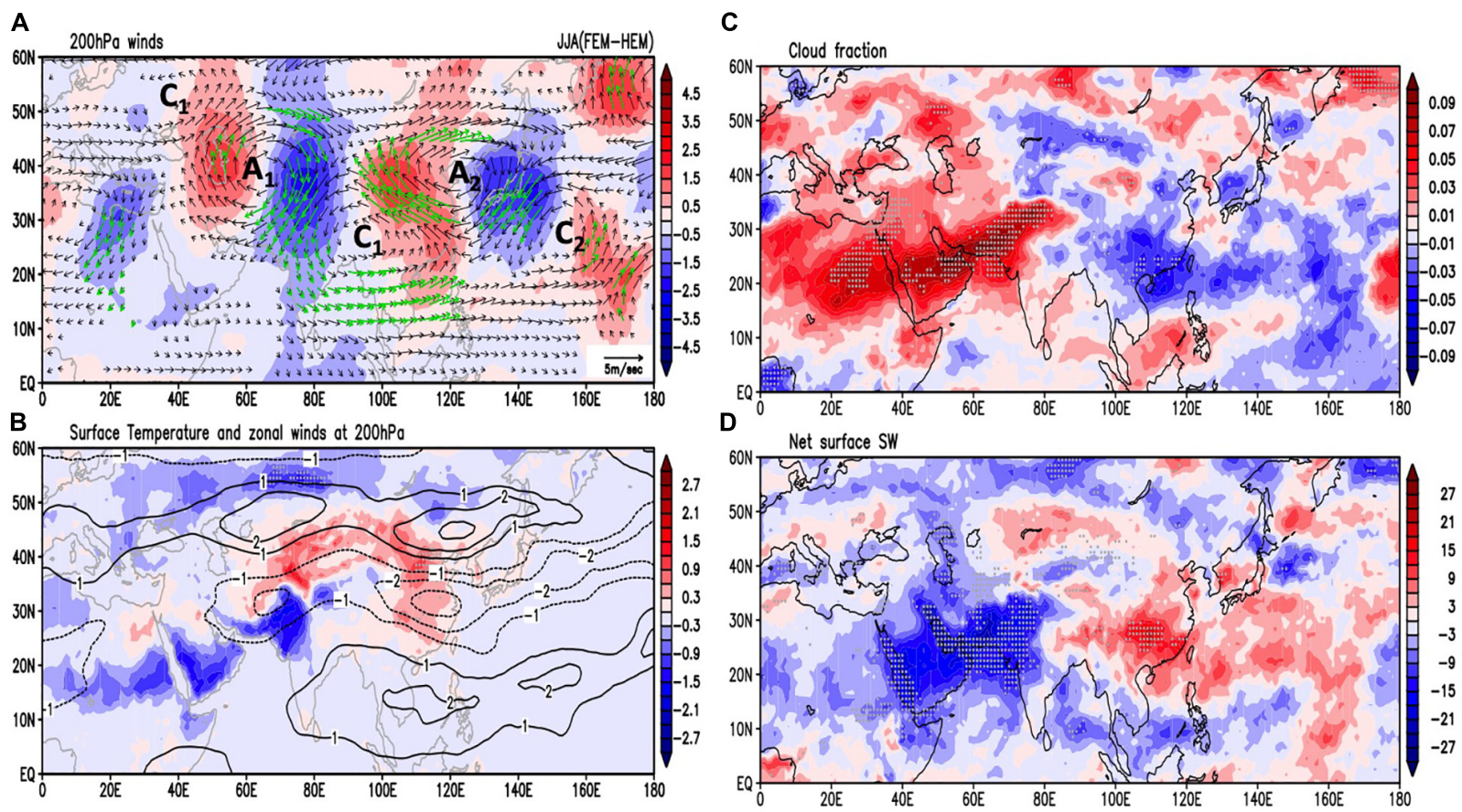

FIGURE 9 | Simulated JJA anomalies in (A) $200 \mathrm{hPa}$ wind vectors, with northerly (southerly) merdional winds indicted by blue (red) shading, (B) 200 hPa zonal winds $\left(\mathrm{ms}^{-1}\right)$ and surface temperature (color shaded), (C) cloud fraction, and (D) surface net downward shortwave radiation (Wm ${ }^{-2}$ ). 


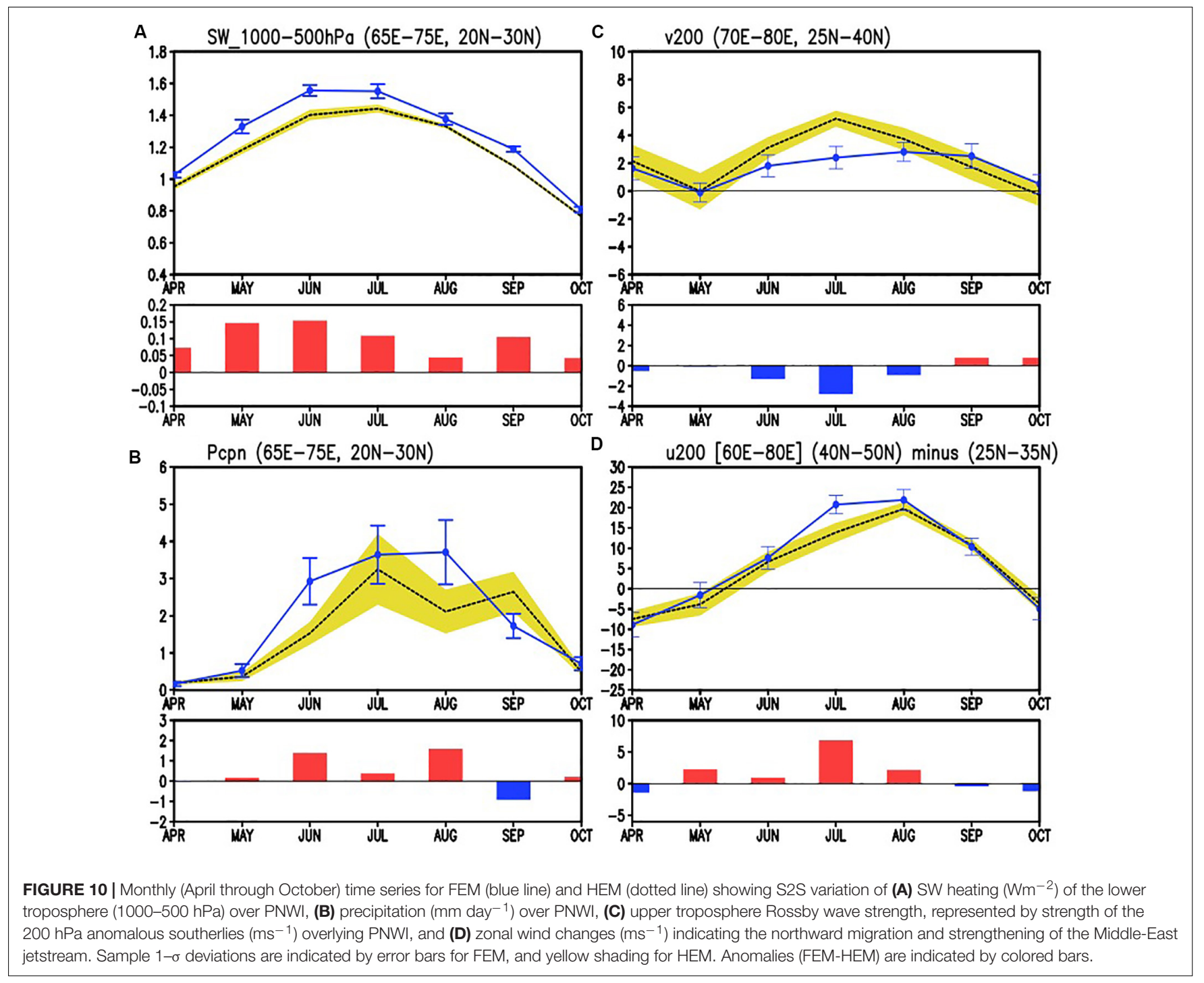

between the wavetrain and jetstream, based on vorticity balance is presented next.

Following Lau et al. (2000), over the ASM region $\left(20-50^{\circ} \mathrm{N}\right.$, $60-140^{\circ} \mathrm{E}$ ), the $200 \mathrm{hPa}$ vorticity is governed approximately by:

$$
\bar{V} \cdot \nabla \zeta^{\prime}+(\bar{\zeta}+\mathrm{f}) \nabla \cdot V^{\prime}=-\beta v^{\prime},
$$

\section{$[\mathrm{VAM}] \quad[\mathrm{DIV}]$}

where $\zeta$ is the vorticity, $\mathrm{f}$ the Coriolis parameter, $\mathrm{V}$, the vector winds, $v$, meridional wind, and the overbar represents monthly climatology, and ()' the anomalies. Notably, from Eq. (1), the anomalous meridional flow of the Rossby wave is governed approximately by contribution from the first term, i.e., vorticity advection by the mean flow [VAM], and the second term, which represents the effect of divergence [DIV] of the anomalous flow associated with precipitation heating. At $200 \mathrm{hPa}$, because of the much stronger zonal compared to meridional winds, VAM is dominated by the mean zonal wind advection. DIV is generally positive in regions of increased precipitation, contributing to a northerly (negative) meridional anomalous v'. The magnitude of DIV is also dependent on the seasonal variation of the mean vorticity $\bar{\zeta}$, mainly contributed by the zonal wind gradient term $\left(-\frac{\partial \bar{u}}{\partial y}\right)$. In the tropics, away from the jet core region, VAM is small, the magnitude of upper level meridional southerly wind can be used as a measure of the strength of the Rossby anticyclone forced by DIV due to increased latent heating from enhanced precipitation (Gill, 1980; Lau and Lim, 1982).

Here, because the higher latitude location of the maximum precipitation over PNWI $\left(25-35^{\circ} \mathrm{N}\right)$ and proximity to the jetstream, both VAM, and DIV contribute to the strength of the Rossby anticyclone, $A_{1}$. This can be seen in the monthto-month variations of key quantities and the anomalies (FEM minus HEM; vertical bars in Figure 10) affecting the vorticity balance of the upper troposphere. The shortwave heating in lower troposphere over the PNWI region increases steadily from April through June, as the dust loading increases due to the prescribed doubling of emission rate from HEM to FEM 


\section{Dust, Cloud Radiation Dynamical interactions in the coupled desert- Asian summer monsoon system}

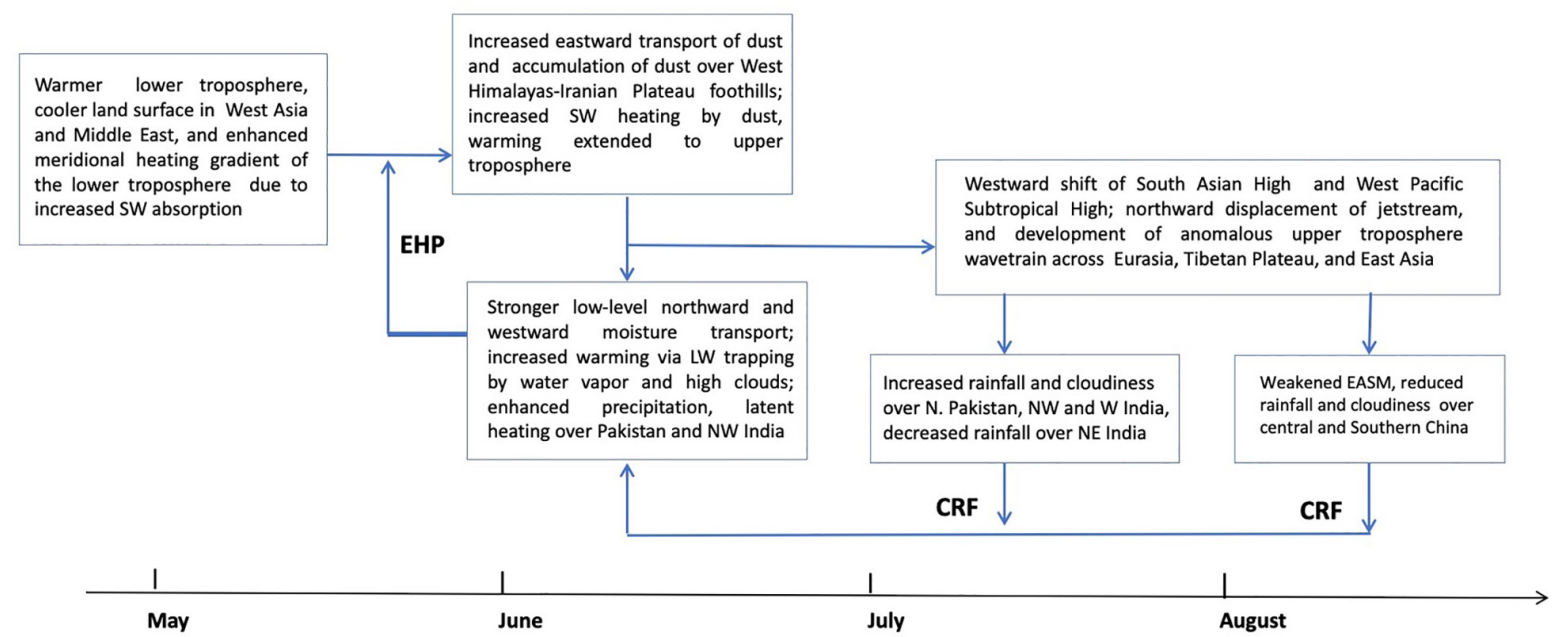

FIGURE 11 | Schematic showing key features of the dust-cloud-radiation-precipitation-circulation feedback and dynamical adjustment processes, triggered by Middle East dust radiation perturbations affecting the coupled desert-ASM system. EHP and CRF denotes, respectively, the aerosol "Elevated Heap Pump" effect, and Cloud-Radiation Feedback.

(Figure 10A), followed by a slow decline in July-August as a result of wash-out by the increasing monsoon seasonal precipitation (Figure 10B). Overall, positive anomalous precipitation is found over the PNWI, signaling an intensification and advance of the monsoon rainy season over the region. Note that the increase is not monotonic, but rather shows a high-low-high variation from June through August (anomalies in Figure 10B). The $200 \mathrm{hPa}$ anomalous meridional winds (Figure 10C) are generally negative (more northerly in FEM) in June through August, consistent with the presence of an upper anticyclone, anchored by increased precipitation over PNWI via the DIV effect. However, the strength of the Rossby wavetrain, as indicated by the anomalous $200 \mathrm{hPa}$ meridional winds exhibit a lowhigh-low magnitude variation from June to August, more in phase with the northward shift and variation of the strength of the jetstream (Figure 10D), indicating strong amplitude modulation by VAM. A separate calculation for the anticyclone $\mathrm{A}_{2}$ yields similar results indicating large contribution by VAM, and strong jetstream-Rossby wave interaction affecting EASM rainfall (Supplementary Figure S3). These results reflect the intrinsic S2S internal dynamics that governs the interaction of monsoon precipitation, quasi-stationary Rossby wavetrain and the jetstream in the monsoon-desert coupled system. More indepth understanding of the dynamics of the interaction, and the roles of cloud radiation feedback requires the decomposition into dominant spatial-temporal modes of monsoon intraseasonal oscillations (MISO), which is outside the scope of this study.

\section{CONCLUSION}

In this study, we have investigated the impact of desert dust on S2S variability of the ASM system, based on numerical experiments using the non-hydrostatic MPAS atmosphere model coupled with the CAM5 physics. Overall, we find that radiative perturbation from increased dust emission and transport from the Middle East/West Asia desert and arid regions induces a strong dust-cloud-radiation-precipitation-circulation feedback, resulting in a cooler land surface over the Middle East desert/West Asia region and the western Tibetan Plateau, but a warmer overlying middle and upper troposphere, with increased moistening, enhanced cloudiness and precipitation over the PNWI region. These changes are accompanied by a northward shift of the upper level jetstream over eastern Europe and the Middle East, in conjunction with an advance of the monsoon rainy season over northwestern and western India. The dust-induced dynamical feedback is underscored by large-scale dynamical adjustment processes, impacting the S2S variability of the Middle East/West Asia desert-monsoon system, illustrated schematically in Figure 11. Specifically, key features include:

1. In May, increased emission of dust over the Middle East desert and West Asia arid regions heats the elevated dust layer in the lower troposphere by absorption of solar radiation, and cools the land surface of the deserts of West Asia and Middle East by shortwave shielding, leading to increasing atmospheric stability through the semi-direct effect. However, the enhanced heating of the dust layer increases the meridional temperature gradient in the lower and mid-troposphere between West Asia land and the North Arabian Sea to the south, facilitating anomalous northward transport of moisture from ocean to the land in the lower troposphere.

2. In June, the meridional heating gradient in the lower troposphere continues to increase, as the advancing monsoon low-level southwesterlies transport more 
dust and moisture over the PNWI region, resulting in anomalous warming and moistening of the lower troposphere over the West Himalayas-Iranian Plateau foothills regions. Eventually, the dust heating overcomes the semi-direct stability effect, and deep convection breaks out above the cooler surface layer. Amplified by the EHP dynamical feedback, the increased convection results in enhanced precipitation over PNWI. The latent heating from precipitation spawns an upper level Rossby wavetrain, with a large-scale anticyclone anchored to the northwest of the precipitation center over PNWI.

3. In July-August, the EHP effect continues, but weakened due to removal of dust aerosol by increasing precipitation washout. However increased precipitation over PNWI continues to evolve due to cloud radiation dynamical feedback, enhancing the meridional surface temperature contrast across the jetstream. This promotes a northward migration of the jetstream which further modulates the magnitude and phase of the upper level Rossby wavertrain, and strength of the monsoon meridional circulation. The net result is a weakening and contraction of the $\mathrm{SAH}$ and a westward displacement the WPSH, with reduced lowlevel southwesterly transport of moisture from India to East Asia, resulting in reduced precipitation over central and southern East Asia.

4. Both the circulation divergence (DIV) associated with increased latent heating from enhanced precipitation over PNWI and vorticity advection by the mean flow (VAM) contribute to the strength and variability of the upper level Rossby wavetrain. In June, when the Middle East jetstream is relatively weak, DIV effect is stronger. In July-August, as the jet migrates northward and strengthens, VAM becomes more dominant.

It is important to note that while our results are based on a state-of-the-art GCM, i.e., MPAS-CAM5, they are from a singular model simulation, and therefore could be dependent on model representation of physical processes. As discussed in section "Results," MPAS-CAM5 has substantial discrepancies in the climatological regional distributions of ASM precipitation and AOD compared to observations. It overestimates the AOD over the desert region, and underestimates that over East Asia, the Indian Ocean, and the western Pacific compared to observations. These could be due to lack of resolution in the dust size distribution, and excessive wet deposition commonly found in climate models, resulting in deficient remote transport of fine dust particles from the source regions (Huneeus et al., 2011). As a result of the excessive AOD, model radiative effects of dust on precipitation may be too strong over the desert and PNWI region, but too weak over East Asia compared to reality. The aforementioned MPAS-CAM5 climatological biases also raise uncertainty regarding the relative importance of dust aerosol vs. cloud feedback processes affecting the ISM vs. EASM. Hence, conclusions in our study need to be treated only qualitatively, and with caution. Further inter-comparison studies with other state-of-the-art climate models, and validation with observations are required.

Last but not least, our findings suggest that the desert and ASM subsystems are intrinsically coupled, through radiation-precipitation-circulation feedback processes, affecting many aspects of S2S variability of the desert-monsoon climate system. The upper tropospheric wavetrain and meridional displacement of the Middle-East/East Asian jetstream unveiled in our study are reminiscent of a host of upper troposphere teleconnection patterns, e.g., ANA, SRP, JMD, and CGT, known to have strong impacts on boreal summer regional S2S variability, and on longer time scales, over Eurasia and Asia, reported in many previous studies cited in section "Wavetrain-jetstream interactions." Of particular relevance is the recent observational study (Xue and Chen, 2019) which showed a distinct north-SAH teleconnection pattern associated with a northward shift of the ASM jetstream, consistent with the weakened and contracted SAH due to increased dust emission from the Middle East desert found in this study. Our results suggest that such teleconnection pattern could be excited through internal feedback mechanisms within the desert-monsoon climate system, without the need for external forcing. How these teleconnection patterns are modulated by additional external forcing such as anomalous SST, anthropogenic emissions of aerosols and greenhouse gases need to be further investigated.

\section{DATA AVAILABILITY STATEMENT}

Data sources used for this work are available from (https: //ladsweb.modaps.eosdis.nasa.gov/) for MODIS AOD, (https:// disc.gsfc.nasa.gov/) for MERRA2, and (https://disc.gsfc.nasa.gov/ datasets/TRMM_3B43_7/summary) for TRMM 3B43 Version 7 monthly rainfall. The raw data supporting the conclusions of this article will be made available by the authors, without undue reservation, to any qualified researcher.

\section{AUTHOR CONTRIBUTIONS}

WL precieved the idea, came up with the experimental design, oversaw the entire research project, and wrote the manuscript. K-MK carried out the analyses, processed the data, plotted the figures, and provided inputs to the manuscript writing. CZ carried out the model simulation experiments, processed the model outputs for analyses, and provided inputs to the manuscript writing. LL provided technical advice, facilitated computational resources, provided revisions to the initial and final draft of the manuscript. S-HP provided technical details on the computational efficiency of variable MPAS model grid, and physic package, and suggested revisions on various drafts of the manuscript. All authors contributed to the article and approved the submitted version. 


\section{FUNDING}

This work was supported by the U.S. Department of Energy (DOE), Office of Science, Biological and Environmental Research as part of the Regional and Global Modeling and Analysis program area, including Grant Award \#30042600001 to U. of Maryland from the Pacific Northwest National Laboratory (PNNL). PNNL is operated for DOE, by Battelle Memorial Institute under contract DE-AC05-76RL01830. CZ was supported by the Fundamental Research Funds for the

\section{REFERENCES}

Abdul-Razzak, H., and Ghan, S. J. (2002). A parameterization of aerosol activation, 3, Sectional representation. J. Geophys. Res. 107, AAC 1-1-AAC 1-6. doi: 10. 1029/2001JD000483

Alfaro, S. C., Lafo, S., Rajot, J. L., Formenti, P., Gaudichet, A., and Maillé, M. (2004). Iron oxides and light absorption by pure desert dust: an experimental study. J. Geophys. Res. 109:D08208. doi: 10.1029/2003JD004374

Badarinath, K. V. S., Kharol, S. K., Kaskaoutis, D. G., Sharma, A. R., Ramaswamy, V., and Kambezidis, H. D. (2010). Long range transport of dust aerosols over the Arabian Sea and Indian region - A case study using satellite data and ground based measurements. Glob. Planet. Change 72, 164-181. doi: 10.1016/ j.gloplacha.2010.02.003

Bollasina, M., Ming, Y., and Ramaswamy, V. (2011). Anthropogenic aerosols and the weakening of the Asian summer monsoon. Science 334, 502-505. doi: 10. $1126 /$ science. 1204994

Bretherton, C. S., and Park, S. (2009). A new moist turbulence parameterization in community atmosphere model. J. Clim. 22, 3422-3448. doi: 10.1175/ 2008JCLI2556.1

Chandra, S., Satheesh, S. K., and Srinivasan, J. (2004). Can the state of mixing of black carbon aerosols explain the mystery of 'excess atmospheric absorption? Geophys. Res. Lett. 31:L19109. doi: 10.1029/2004GL020662

Chu, J.-E., Kim, K.-M., Lau, W. K. M., and Ha, K.-J. (2018). How light absorbing properties of organic aerosol modify the Asian summer monsoon rainfall? J. Geophys. Res. Atmos. 123, 2244-2255. doi: 10.1002/2017JD02 7642

Das, S., Dey, S., Dash, S. K., Giuliani, G., and Solmon, F. (2015). Dust aerosol feedback on the Indian summer monsoon: sensitivity to absorption property. J. Geophys. Res. Atmos. 120, 9642-9652. doi: 10.1002/2015JD023589

Deepshikha, S., Satheesh, S. K., and Srinivasan, J. (2005). Regional distribution of absorbing efficiency of dust aerosols over India and adjacent continents inferred using satellite remote sensing. Geophys. Res. Lett. 32:L03811. doi: 10. 1029/2004GL022091

di Sarra, A., Di Biagio, C., Meloni, D., Monteleone, F., Pace, G., Pugnaghi, S., et al. (2011). Shortwave and longwave radiative effects of the intense Saharan dust event of 25-26 March 2010 at Lampedusa (Mediterranean Sea). J. Geophys. Res. 116:D23209. doi: 10.1029/2011JD016238

Ding, Q. H., and Wang, B. (2005). Circumglobal teleconnection in the Northern Hemisphere summer. J. Clim. 18, 3483-3505. doi: 10.1175/JCLI3473.1

Ding, Q. H., and Wang, B. (2007). Intraseasonal teleconnection between the summer Eurasian wavetrain, and the Indian monsoon. J. Clim. 20, 3751-3776. doi: 10.1175/JCLI4221.1

Ding, Y., and Chan, J. (2005). The East Asian summer monsoon: an overview. Meteorol. Atmos. Phys. 89, 117-142. doi: 10.1007/s00703-005-0125-Z

Du, Y., Li, T., Xie, Z., and Zhu, Z. (2016). Interannual variability of the Asian subtropical westerly jet in boreal summer and associated with circulation and SST anomalies. Clim. Dyn. 46, 2673-2688. doi: 10.1007/s00382-0152723-x

Enomoto, T. (2004). Interannual variability of the Bonin high associated with the propagation of Rossby waves along the Asian jet. J. Meteor. Soc. Japan 82, 1019-1034. doi: 10.2151/jmsj.2004.1019

Enomoto, T., Hoskins, B. J., and Matsuda, Y. (2003). The formation mechanism of the Bonin high in August. Q. J. R. Meteorl. Soc. 129, 157-178. doi: 10.1256/qj. 01.211
Central Universities of China and the National Natural Science Foundation of China (grant 41775146). Most of this work was completed while he was a research scientist at PNNL.

\section{SUPPLEMENTARY MATERIAL}

The Supplementary Material for this article can be found online at: https://www.frontiersin.org/articles/10.3389/feart. 2020.00226/full\#supplementary-material

Evan, A. T., Flamant, C., Fiedler, S., and Doherty, O. (2014). An analysis of aeolian dust in climate models. Geophys. Res. Lett. 41, 5996-6001. doi: 10.1002/ 2014GL060545

Evans, J. P. (2011). "CORDEX - An international climate downscaling initiative," in Proceedings of the 19th International Congress on Modelling and Simulation, Perth.

Flanner, M., and Zender, C. S. (2005). Snowpack radiative heating: influence on Tibetan Plateau climate. Geophys. Res. Lett. 32:L06501. doi: 10.1029/ 2004 gl022076

Flanner, M., Zender, C. S., Randerson, T. J., and Rasch, P. J. (2007). Presentday climate forcing and response from black carbon in snow. J. Geophys. Res. 112:D11202. doi: 10.1029/2006JD008003

Gautam, R., Hsu, C., and Lau, K. M. (2010). Pre-monsoon characterization and radiative effects over the Indo-Gangetic plain: implications for regional climate warming. J. Geophys. Res. 115:D17208. doi: 10.1029/2010JD0

Gautam, R., Hsu, N. C., Lau, K. M., and Kafatos, M. (2009a). Aerosol and rainfall variability over the Indian monsoon region: distributions, trends and coupling. Ann. Geophys. 27, 3691-3703. doi: 10.5194/angeo-27-3691-2009

Gautam, R., Liu, Z., Singh, R. P., and Hsu, N. C. (2009b). Two contrasting dust-dominant periods over India observed from MODIS and CALIPSO data. Geophys. Res. Lett. 36:L06813. doi: 10.1029/2008GL036967

Gautam, R., Hsu, N. C., Tsay, S. C., Lau, K. M., Holben, B., Bell, S., et al. (2011). Accumulation of aerosols over the Indo-Gangetic plains and southern slopes of the Himalayas: distribution, properties and radiative effects during the 2009 pre-monsoon season. Atmos. Chem. Phys. 11, 12841-12863. doi: 10.5194/acp11-12841-2011

Ghan, S. J., and Zaveri, R. A. (2007). Parameterization of optical properties for hydrated internally mixed aerosol. J. Geophys. Res. 112:D10201. doi: 10.1029/ 2006JD007927

Giles, D. M., Holben, B. N., Eck, T. F., Sinyuk, A., Smirnov, A., Slutsker I., et al. (2012). An analysis of AERONET aerosol absorption properties and classifications representative of aerosol source regions. J. Geophys. Res. 117:D17203. doi: 10.1029/2012JD018127

Gill, A. E. (1980). Some simple solutions for heat-induced tropical circulation. Q. J. R. Meteorol. Soc. 106, 447-462. doi: 10.1002/qj.49710644905

Hansen, J., Sato, M., and Ruedy, R. (1997). Radiative forcing and climate response. J. Geophys. Res. 102, 6831-6864. doi: 10.1029/96jd03436

Holton, J. R. (1993). An Introduction to Dynamic Meteorology, 3rd Edition, 48, International Geophysics Series. Cambridge, MA: Academic Press.

Hong, X., and Lu, R. (2016). The meridional displacement of the summer Asian Jet, Silk Road Pattern, and tropical SST anomalies. J. Clim. 29, 3753-3766. doi: 10.1175/JCLI-D-15-0541.1

Hoskins, B. J., and Ambrizzi, T. (1993). Rossby wave propagation on a realistic longitudinally varying flow. J. Atmos. Sci. 50, 1661-1671. doi: 10.1175/15200469(1993)050<1661:rwpoar>2.0.co;2

Huang, J., Fu, Q., Su, J., Tang, Q., Minnis, P., Hu, Y., et al. (2009). Taklimakan dust aerosol radiative heating derived from CALIPSO observations using the Fu-Liou radiation model with CERES constraints. Atmos. Chem. Phys. 9, 4011-4021. doi: 10.5194/acp-9-4011-2009

Huneeus, N., Schulz, M., Balkanski, Y., Griesfeller, J., Prospero, M., Kinne, S., et al. (2011). Global dust model intercomparison in AeroCom phase I. Atmos. Chem. Phys. 11, 7781-7816. doi: 10.5194/acp-11-7881-2011

Iacono, M. J., Mlawer, E. J., Clough, S. A., and Morcrette, J. J. (2000). Impact of an improved longwave radiation model, RRTM, on the energy budget and 
thermodynamic properties of the NCAR community climate model, CCM3. J. Geophys. Res. 105, 14873-14890. doi: 10.1029/2000JD900091

Jin, Q., Wei, J., and Yang, Z. L. (2014). Positive response of Indian summer rainfall to Middle East dust. Geophys. Res. Lett. 41, 4068-4074. doi: 10.1002/ 2014GL059980

Jin, Q., Yang, Z., and Wei, J. (2016). Seasonal responses of indian summer monsoon to dust aerosols in the Middle East, India, and China. J. Clim. 29, 6329-6349. doi: 10.1175/JCLI-D-15-0622.1

Kim, M. K., Lau, W. K. M., Kim, K., Sang, J., Kim, Y., and Lee, W. (2015). Amplification of ENSO effects on Indian summer monsoon by absorbing aerosols. Clim. Dyn. 46:2657. doi: 10.1007/s00382-015-2722-y

Kok, J. F. (2011). A scaling theory for the size distribution of emitted dust aerosols suggests climate models underestimate the size of the global dust cycle. Proc. National Acad. Sci. U.S.A. 108, 1016-1021. doi: 10.1073/pnas.1014798108

Lamarque, J. F., Bond, T. C., Eyring, V., Granier, C., Heil, A., Klimont, Z., et al. (2010). Historical (1850-2000) gridded anthropogenic and biomass burning emissions of reactive gases and aerosols: methodology and application. Atmos. Chem. Phys. Eur. Geosci. Union 10, 7017-7039. doi: 10.5194/acp-10-7017-2010

Lau, K. M., Kim, K. M., and Kim, M. K. (2006). Asian summer monsoon anomalies induced by aerosol direct forcing: the role of the Tibetan Plateau. Clim. Dyn. 26, 855-864. doi: 10.1007/s00382-006-0114-z

Lau, K. M., Kim, K. M., and Yang, S. (2000). Dynamical and boundary forcing characteristics of regional components of the asian summer monsoon. J. Clim. 13, 2461-2482. doi: 10.1175/1520-0442(2000)013<2461:dabfco >2.0.co;2

Lau, K. M., Kim, M. K., Kim, K. M., and Lee, W. (2010). Enhanced surface warming and accelerated snow melt in the Himalayas and Tibetan Plateau induced by absorbing aerosols. Environ. Res. Lett. 5:025204. doi: 10.1088/1748-9326/5/2/ 025204

Lau, K. M., and Li, M. T. (1984). The monsoon of east-asia - a survey. Bull. Am. Meteorl. Soc. 65, 114-125.

Lau, K. M., and Lim, H. (1982). Thermally driven motions in an equatorial $\beta$-plane: hadley and Walker circulations during the winter monsoon. Mon. Wea. Rev. 110, 1372-1388.

Lau, K. M., Ramanathan, V., Wu, G.-X., Li, Z., Tsay, S. C., and Hsu, C. (2008). The joint aerosol-monsoon experiment: a new challenge for monsoon climate research. Bull. Am. Meteorol. Soc. 89, 369-383. doi: 10.1175/BAMS-89-3-369

Lau, K. M., and Weng, H. (2002). Recurrent teleconnection patterns linking summer monsoon variability over East Asia and North America. J. Meteor. Soc. Japan 80, 1309-1324. doi: 10.2151/jmsj.80.1309

Lau, W. K. M. (2014). Desert dust and monsoon rain. Nat. Geosci. 7, 255-256. doi: $10.1038 /$ ngeo 2115

Lau, W. K. M. (2016). The aerosol-monsoon climate system of asia: a new paradigm. J. Meteorl. Res. 29, 1-11. doi: 10.1007/s13351-015-5999-1

Lau, W. K. M., and Kim, K. M. (2018). Impacts of snow-darkening by deposition of light-absorbing aerosols on snowcover over the Himalayas-Tibetan-Plateau, and influences on the Asian summer monsoon: a possible mechanism for the Blanford Hypothesis. Atmosphere 9:438. doi: 10.3390/atmos9110438

Lau, W. K. M., Kim, K. M., Chern, J., Tao, W. K., and Leung, R. (2019). Structural change and variability of the ITCZ induced by radiation-cloud-convectioncirculation interactions: inferences from the Goddard Multi-Model Framework (GMMF) experiments. Clim. Dyn. 54, 211-229. doi: 10.1007/s00382-01905000-y

Leung, L. R., Mearns, L. O., Giorgi, F., and Wilby, R. L. (2003). Regional climate research. Bull. Am. Meteorol. Soc. 84, 89-95.

Leung, L. R., Ringler, T. D., Collins, W. D., and Ashfaq, M. (2013). A hierarchical evaluation of regional climate simulations. EOS Trans. AGU 94, 297-298. doi: $10.1002 / 2013$ eo340001

Li, Z., Lau, W. K. M., Ramanathan, V., Wu, G., Ding, Y., Manoj, M. G., et al. (2016). Aerosol and Monsoon Climate Interactions over Asia. Rev. Geophys. $54,866-929$.

Liu, X., Easter, R. C., Ghan, S. J., Zaveri, R., Rasch, P., Shi, X., et al. (2012). Toward a minimal representation of aerosols in climate models: description and evaluation in the Community Atmosphere Model CAM5. Geosci. Model Dev. 5, 709-739. doi: 10.5194/gmd-5-709-2012

Liu, X., Pennerc, J. E., Ghan, S. J., and Wang, M. (2007). Inclusion of ice microphysics in the NCAR community atmospheric model version 3 (CAM3). J. Clim. 20, 4526-4547. doi: 10.1175/JCLI4264.1
Lohmann, U., and Feichter, J. (2001). Can the direct and semi-direct aerosol effect compete with the indirect effect on a global scale? Geophys. Res. Lett. 28, 159-161. doi: 10.1029/2000GL012051

Lu, R., Oh, J. H., and Kim, B. J. (2002). A teleconnection pattern in upper-level meridional wind over the North African and Eurasian continent in summer. Tellus 54A, 44-55. doi: 10.1034/j.1600-0870.2002.00248.x

Meehl, G. A., Arblaster, J., and Collins, W. (2008). Effects of black carbon aerosols on the Indian monsoon. J. Clim. 21, 2869-2882. doi: 10.1175/2007JCLI1777.1

Mlawer, E. J., Iacono, M. J., Pincus, R., Barker, H. W., Oreopoulos, L., and Mitchell, D. L. (2016). Contributions of the ARM program to radiative transfer modeling for climate and weather applications. Meteorol. Monogr. 57, 15.1-15.19. doi: 10.1175/AMSMONOGRAPHS-D-15-0041.1

Moorthy, K. K., Babu, S. S., Satheesh, S. K., Srinivasan, J., and Dutt, C. B. S. (2007). Dust absorption over the "Great Indian Desert" inferred using groundbased and satellite remote sensing. J. Geophys. Res. 112:D09206. doi: 10.1029/ 2006JD007690

Morrison, H., and Gettelman, A. (2008). A new two-moment bulk stratiform cloud microphysics scheme in the community atmosphere model, Version 3 (CAM3). Part I: description and numerical tests. J. Clim. 21, 3642-3659. doi: 10.1175/2008JCLI2105.1

Neale, R. B., Richter, J. H., Conley, A. J., Park, S., Lauritzen, P. H., Gettelman, A., et al. (2012). Description of the NCAR Community Atmosphere Model (CAM5.0). NCAR Technical Note, NCAR/TN-486+STR, National Center for Atmospheric Research, 274. Available online at: http://www.cesm.ucar.edu/models/cesm1.0/ cam/docs/description/cam5_desc.pdf

Pan, X., Chin, M., Gautam, R., Bian, H., Kim, D., Colarco, P., et al. (2015). A multimodel evaluation of aerosols over South Asia: common problems and possible causes. Atmos. Chem. Phys. 15, 5903-5928. doi: 10.5194/acp-15-5903-2015

Pandithurai, G., Dipu, S., Dani, K. K., Tiwari, S., Bisht, D. S., Devara, P. C. S., et al. (2008). Aerosol radiative forcing during dust events over New Delhi, India. J. Geophys. Res. 113:D13209. doi: 10.1029/2008JD009804

Prasad, A. K., and Singh, R. P. (2007). Changes in aerosol parameters during major dust storm events (2001-2005) over the indo-gangetic plains using AERONET and MODIS data. J. Geophys. Res. 112:D09208. doi: 10.1029/2006JD007778

Qian, Y., Gustafson, W. I., Leung, L. R., and Ghan, S. J. (2009). Effects of soot-induced snow albedo change on snowpack and hydrological cycle in western United States based on Weather Research and Forecasting chemistry and regional climate simulations. J. Geophys. Res. 114:D03108. doi: 10.1029/ 2008JD011039

Qian, Y., Yasunari, T. J., Doherty, S. J., Flanner, M. G., Lau, W. K. M., Ming, J., et al. (2015). Light-absorbing particles in snow and ice: measurement and modeling of climatic and hydrological impact. Adv. Atmos. Sci. 32, 64-91. doi: 10.1007/s00376-014-0010-0

Ramachandran, S. (2005). Pre-monsoon shortwave aerosol radiative forcing over the Arabian Sea and tropical Indian Ocean: yearly and monthly mean variabilities. J. Geophys. Res. 110:D07207. doi: 10.1029/2004JD00 5563

Ramanathan, V., Chung, C., Kim, D., Bettge, T., Buja, L., Kiehl, T. J., et al. (2005). Atmospheric brown clouds: impacts on South Asian climate and hydrological cycle. Proc. Natl. Acad. Sci. U.S.A. 102, 5326-5333. doi: 10.1073/ pnas. 0500656102

Ramanathan, V., and Collins, W. (1991). Thermodynamic regulation of ocean warming by cirrus clouds deduced from observations of the 1987 El Niño. Nature 351, 27-32. doi: 10.1038/351027a0

Rodwell, M. J., and Hoskins, B. J. (1995). A model for the Asian summer monsoon. Part II: cross-equatorial flow and PV behavior. J. Atmos. Sci. 52, 1341-1356. doi: 10.1175/1520-0469(1995)052<1341:amotas $>2.0 . c 0 ; 2$

Rosenfeld, D., Lohmann, U., Raga, G. B., O’Dowd, C. D., Kulmala, Fuzzi, M. S., et al. (2008). Flood or drought: how do aerosols affect precipitation? Science 321, 1309-1313. doi: 10.1126/science.1160606

Sakaguchi, K., Leung, L. R., Zhao, C., Yang, Q., Lu, J., Hagos, S. M., et al. (2015). Exploring a multi-resolution approach using AMIP simulations. J. Clim. 28, 5549-5574. doi: 10.1175/JCLI-D-14-00729.1

Sakaguchi, K., Lu, J., Leung, L. R., Zhao, C., Li, Y., and Hagos, S. (2016). Sources and pathways of the upscale effects on the Southern Hemisphere jet in MPASCAM4 variable-resolution simulations. J. Adv. Model. Earth Syst. 8, 1786-1805. doi: $10.1002 / 2016 \mathrm{MS} 000743$ 
Sanap, S. D., and Pandithurai, G. (2015). The effect of absorbing aerosol on Indian monsoon circulation and rainfall: a review. Atmos. Res. 16, 318-327. doi: 10.1016/j.atmosres.2015.06.002

Satheesh, S., Krishna Moorthy, K., Kaufman, Y., Kaufman, J., and Takemura, T. (2006). Aerosol optical depth, physical properties, and radiative forcing over the Arabian Sea. Meteorol. Atmos. Phys. 91:45. doi: 10.1007/s00703-0040097-4

Satheesh, S. K., Krishna Moorthy, K., Babu, S. S., Vinoj, V., and Dutt, C. B. C. (2008). Climate implications of large warming by elevated aerosol over India. Geophys. Res. Lett. 35:L19809. doi: 10.1029/2008GL034944

Satheesh, S. K., and Srinivasan, J. (2002). Enhanced aerosol loading over Arabian Sea during the pre-monsoon season: natural or anthropogenic? Geophys. Res. Lett. 29:1874. doi: 10.1029/2002GL015687

Sato, N., and Takahashi, M. (2003). Formation mechanism of vorticity anomalies on the subtropical jet in the midsummer Northern Hemisphere. Appl. Mech. Jpn. 52, 109-115. doi: 10.11345/nctam.52.109

Skamarock, W. C., Klemp, J. B., Fowler, L. D., Duda, M. G., Park, S. H., and Ringler, T. D. (2012). A multiscale nonhydrostatic atmospheric model using centroidal Voronoi tesselations and C-grid staggering, Mon. Weather Rev. 140, 3090-3105. doi: 10.1175/MWR-D-11-00215.1

Sokolik, I. N., and Toon, O. B. (1999). Incorporation of mineralogical composition into models of the radiative properties of mineral aerosol from UV to IR wavelengths. J. Geophys. Res. 104, 9423-9444. doi: 10.1029/1998jd20 0048

Solmon, F., Mallet, F., Elguindi, N., Giorgi, F., Zakey, A., and Konaré, A. (2008). Dust aerosol impact on regional precipitation over western Africa, mechanisms and sensitivity to absorption properties. Geophys. Res. Lett. 35:L24705. doi: 10.1029/2008GL035900

Solmon, F., Nair, V. S., and Mallet, M. (2015). Increasing Arabia dust activity and the Indian summer monsoon. Atmos. Chem. Phys. 15, 8051-8064. doi: 10.5194/acp-12-8051-2015

Song, F., Zhou, T., and Wang, L. (2013). Two modes of the Silk Road pattern and their interannual variability simulated by LASG/IAP AGCM SAMIL2.0. Adv. Atmos. Sci. 30, 908-921. doi: 10.1007/s00376-012-2145-1

Stephan, C. C., Klingman, N. P., and Turner, A. G. (2018). A mechanism for the recently increased interdecadal variability of the Silk Road Pattern. J. Clim. 32, 717-736. doi: 10.1175/Jc:I-D18-0405.1

Vinoj, V., Rasch, P. J., Wang, H., Yoon, J., Ma, P., Landu, K., et al. (2014). Shortterm modulation of Indian summer monsoon rainfall by West Asian dust. Nat. Geosci. 7, 308-313. doi: 10.1038/ngeo2107

Wakabayashi, S., and Kawamura, R. (2004). Extraction of major teleconnection patterns possibly associated with the anomalous summer climate in Japan. J. Meteor. Soc. Jpn. 82, 1577-1588. doi: 10.2151/jmsj.82.1577

Wang, B. (2006). The Asian Monsoon, Editor, Wang B. Chichester: Springer-Praxis Ltd.

Wang, B. (2009). Distinct principal modes of early and late summer rainfall anomalies in East Asia. J. Clim. 22, 3864-3875. doi: 10.1175/2009jcli2850.1

Wang, C., Jeong, G. R., and Mahowald, N. (2009a). Particulate absorption of solar radiation: anthropogenic aerosols vs. dust. Atmos. Chem. Phys. 9, 3935-3945. doi: 10.5194/acp-9-3935-2009
Wang, C., Kim, D., Ekman, M. L., Barth, M. C., and Rasch, P. J. (2009b). Impact of anthropogenic aerosols on Indian summer monsoon. Geophys. Res. Lett. 36:L21704. doi: 10.1029/2009GL040114

Wang, L., Xu, P., Chen, W., and Liu, Y. (2017). Interdecadal variations of the silk road pattern. J. Clim. 30, 9915-9932. doi: 10.1175/JCLI-D-17-0340.1

Wei, Q. J., and Yang, Z. L. (2014). Positive response of Indian summer rainfall to Middle East dust. Geophys. Res. Lett. 41, 4068-4074 .

Wu, G., Li, Z., Fu, C., Zhang, X., Zhang, R., Zhang, R., et al. (2016). Advances in studying interaction of aerosol and monsoon in China. Sci. China Earth Sci. 59:1. doi: 10.1007/s11430-015-5198-Z

Xia, X., and Zong, X. (2009). Shortwave versus longwave direct radiative forcing by Taklimakan dust aerosols. Geophys. Res. Lett. 36:L07803. doi: 10.1029/ 2009GL037237

Xue, X., and Chen, W. (2019). Distinguishing interannual variations and possible impacted factors for the northern and southern mode of South Asia High. Clim. Dyn. 53, 4937-4959. doi: 10.1007/s00382-019-04837-7

Zender, C. S., Bian, H., and Newman, D. (2003). Mineral dust entrainment and deposition (DEAD) model: description and 1990s dust climatology. J. Geophys. Res. 108:4416.

Zhang, G. J., and McFarlane, N. A. (1995). Sensitivity of climate simulations to the parameterization of cumulus convection in the Canadian climate center general circulation model. Atmos. Ocean 33, 407-446. doi: 10.1080/07055900. 1995.9649539

Zhang, M., Zhao, C., Cong, Z., Du, Q., Xu, M., Chen, Y., et al. (2020). Impact of topography on black carbon transport to the southern Tibetan Plateau during pre-monsoon season and its climatic implication. Atmos. Chem. Phys. 19, 5529-5541. doi: 10.5194/acp-2019-905

Zhang, Y., Kuang, X., Guo, W., and Zhou, T. (2006). Seasonal evolution of the upper-tropospheric westerly jet core over East Asia. Geophys. Res. Lett. 33:L11708. doi: 10.1029/2006GL026377

Zhao, C., Leung, L. R., Park, S. H., Hagos, S., Lu, J., Sakaguchi, K., et al. (2016). Exploring the impacts of physics and resolution on aqua-planet simulations from a non-hydrostatic global variable-resolution modeling framework. J. Adv. Model. Earth Syst. 8, 1751-1768. doi: 10.1002/2016MS00 0727

Zhao, C., Xu, M., Wang, Y., Zhang, M., Guo, J., Leung, R. L., et al. (2019). Modeling extreme precipitation over East China with a global variableresolution modelling framework (MPASv5.2). Geosci. Model Dev. 12, 27072726. doi: 10.5194/gmd-12-2707-2019

Conflict of Interest: The authors declare that the research was conducted in the absence of any commercial or financial relationships that could be construed as a potential conflict of interest.

Copyright (C) 2020 Lau, Kim, Zhao, Leung and Park. This is an open-access article distributed under the terms of the Creative Commons Attribution License (CC BY). The use, distribution or reproduction in other forums is permitted, provided the original author(s) and the copyright owner(s) are credited and that the original publication in this journal is cited, in accordance with accepted academic practice. No use, distribution or reproduction is permitted which does not comply with these terms. 